\title{
Deep-water dunes on drowned isolated carbonate terraces (Mozambique Channel, south-west Indian Ocean)
}

\author{
Miramontes Elda ${ }^{1,}{ }^{*}$, Jorry Stephan ${ }^{2}$, Jouet Gwenael ${ }^{2}$, Counts John ${ }^{3}$, Courgeon Simon ${ }^{4}$, Roy Philippe \\ ${ }^{1}$, Guerin Charline ${ }^{2}$, Hernández-Molina F. Javier ${ }^{5}$
}

${ }^{1}$ UMR6538; CNRS-UBO; IUEM; Laboratoire Géosciences Océan; 29280 Plouzané, France

2 IFREMER; Géosciences Marines; 29280 Plouzané ,France

${ }^{3}$ School of Earth Sciences; University College Dublin; Belfield, Dublin 4 ,Ireland

${ }^{4}$ University of Geneva; Department of Earth Sciences; 1205 Geneva, Switzerland

${ }^{5}$ Department of Earth Sciences; Royal Holloway; University of London; Egham Surrey TW20 0EX, United Kingdom

* Corresponding author : Elda Miramontes, email address : Elda.Miramontesgarcia@univ-brest.fr

\begin{abstract}
:
Subaqueous sand dunes are common bedforms on continental shelves dominated by tidal and geostrophic currents. However, much less is known about sand dunes in deep-marine settings that are affected by strong bottom currents. In this study, dune fields were identified on drowned isolated carbonate platforms in the Mozambique Channel (south-west Indian Ocean). The acquired data include multibeam bathymetry, multi-channel high-resolution seismic reflection data, sea floor imagery, a sediment sample and current measurements from a moored current meter and hull-mounted acoustic Doppler current profiler. The dunes are located at water depths ranging from 200 to $600 \mathrm{~m}$ on the slope terraces of a modern atoll (Bassas da India Atoll) and within small depressions formed during tectonic deformation of drowned carbonate platforms (Sakalaves Seamount and Jaguar Bank). Dunes are composed of bioclastic medium size sand, and are large to very large, with wavelengths of 40 to $350 \mathrm{~m}$ and heights of 0.9 to $9.0 \mathrm{~m}$. Dune migration seems to be unidirectional in each dune field, suggesting a continuous import and export of bioclastic sand, with little sand being recycled. Oceanic currents are very intense in the Mozambique Channel and may be able to erode submerged carbonates, generating carbonate sand at great depths. A mooring located at $463 \mathrm{~m}$ water depth on the Hall Bank (30 km west of the Jaguar Bank) showed vigorous bottom currents, with mean speeds of $14 \mathrm{~cm} \mathrm{sec}-1$ and maximum speeds of $57 \mathrm{~cm} \mathrm{sec}-1$, compatible with sand dune formation. The intensity of currents is highly variable and is related to tidal processes (high-frequency variability) and to anticyclonic eddies near the seamounts (low-frequency variability). This study contributes to a better understanding of the formation of dunes in deep-marine settings and provides valuable information about carbonate preservation after drowning and the impact of bottom currents on sediment distribution and sea floor morphology.
\end{abstract}

Keywords : Bedform, bottom currents, contourite, deep-marine environment, eddy, geostrophic current, oceanic circulation 


\section{INTRODUCTION}

Submarine sand dunes have been observed worldwide on continental shelves exposed to tidal currents and geostrophic flows (Flemming, 1980; Viana et al.; 1998; Franzetti et al., 2013). In contrast, few cases have been identified on present-day continental slopes or in deep-marine

This article is protected by copyright. All rights reserved. 
settings (King et al., 2014). In deep-marine environments, sandy deposits are usually interpreted as being transported by gravity processes, with oceanographic processes often being neglected as a viable alternative transport mechanism (Viana et al., 1998; Hernández-Molina et al., 2017). However, sand dunes can be formed in deep areas where bottom currents are energetic enough to erode, transport and deposit sands. The development of sand dunes depends on the hydrodynamic regime (for example, geostrophic currents, tidal currents, internal waves and eddies), sediment availability, sediment composition and grain-size, local topography, climate and sea-level fluctuations (Allen, 1968). Most of the observed deep-water sand dunes published in the literature correspond to barchan or barchanoid dunes. Good examples have been reported from the Carnegie Ridge in the eastern equatorial Pacific (Lonsdale \& Malfait, 1974), the Faroe-Shetland Channel (Wynn et al., 2002), the Gulf of Cadiz (Hanquiez et al., 2007) and the Gulf of Mexico (Kenyon et al., 2002), and from the ancient record of continental slopes in Brazil (Mutti et al., 2014), Uruguay (Hernández-Molina et al., 2017), eastern Canada (Campbell et al., 2016) and Morocco (Capella et al., 2017). Fields of transverse dunes have also been identified on both the Carnegie Ridge (Lonsdale \& Malfait, 1974) and the Maldives carbonate platform (Betzler et al., 2009; Lüdmann et al., 2013), as well as on continental slopes associated with geostrophic currents, for example in the Barents Sea (King et al., 2014; Bøe et al., 2015), on the south-eastern Brazilian margin (Viana, 2001) and in the Gulf of Cadiz (Hanquiez et al., 2007; Hernández-Molina et al., 2016). Submarine dunes related to internal waves have been reported from the South China Sea (Reeder et al., 2011) and in the Messina Strait (Droghei et al., 2016).

The dynamics of sand dunes and the strong currents forming them can be a hazard for submarine seabed engineering operations and infrastructure, such as pipelines, cables or platforms (Bøe et al., 2015). Understanding the formation and evolution of coarse-grained bedforms can also provide useful information for palaeoceanographic reconstructions and for hydrocarbon exploration (Viana \& Rebesco, 2007; Hernández-Molina et al., 2017). The main aims of this study are to: (i) characterize the distribution and extent of the dune fields on the top of some drowned carbonate

This article is protected by copyright. All rights reserved. 
platforms; (ii) analyze the dune morphometrics; and (iii) examine the oceanographic context of the dune fields in question.

\section{REGIONAL SETTING}

\section{Geological context}

The Mozambique Channel is a north-south oriented elongate basin in the south-west Indian Ocean, bounded by the African continent to the west and by Madagascar to the east. Its depth ranges between $2700 \mathrm{~m}$ (in the north at the narrowest part of the channel) and $5000 \mathrm{~m}$ (in the southern part of the channel) (Fig. 1). The Mozambique Channel is the result of the breakup of Gondwana during the Early Jurassic-Early Cretaceous (Mahanjane, 2014, and references therein). The southward drift of Madagascar relative to Africa occurred from the Middle Jurassic to the Early Cretaceous through a major transform fault currently expressed by a NNW-SSE trend bathymetric high named the Davie Ridge (Fig. 1; Coffin \& Rabinowitz, 1987).

The Sakalaves Seamount studied here is a $\mathbf{5 0 0 ~} \mathrm{m}$ deep flat-topped seamount that is part of the Davie Ridge structure. It originated as a shallow-water carbonate platform (Fig. 1; Courgeon et al., 2016). The southern central part of the Mozambique Channel contains both a modern atoll (Bassas da India), and several drowned carbonate platforms (the Hall and Jaguar banks and part of Bassas da India) that originally developed atop submarine volcanoes (Fig. 1; Courgeon et al., 2016). The initiation of shallow-water carbonate sedimentation is thought to have taken place at the Sakalaves Seamount and in the Southern Mozambique Channel during Oligocene and Early Miocene times, respectively (Courgeon et al., 2016). The major drowning events occurred during the Upper Miocene-Lower Pliocene, and probably were triggered by extensional tectonic deformation and/or renewed volcanism (Courgeon et al., 2017). The tectonic and volcanic activities that affected the seamounts and the associated isolated carbonate platforms were likely related to the development of the East African Rift System (Courgeon et al., 2016, 2018; Deville et al., 2018).

This article is protected by copyright. All rights reserved. 


\section{Oceanographic context}

The surface oceanic circulation in the Mozambique Channel forms part of the greater Agulhas Current system that extends from the north of Madagascar to South Africa (Lutjeharms, 2006). The Agulhas Current is the strongest western boundary current in the southern hemisphere, being an important link in the exchange of heat and salt between the Indian and Atlantic oceans (Gordon, 1986; Weijer et al., 1999). Currents in the Mozambique Channel are very complex and intense; they comprise a southward-bound, western boundary current (DiMarco et al., 2002; Quartly et al., 2013; Flemming \& Kudrass, 2018) and large ( $\geq 300 \mathrm{~km}$ diameter), southward migrating, anticyclonic eddies that can affect the entire water column (de Ruijter et al., 2002; Lutjeharms et al., 2012; Halo et al., 2014) (Fig. 1). Four to seven eddies commonly pass through the Mozambique Channel every year (Schouten et al., 2003). The formation of these eddies is related to the South Equatorial Current (SEC) (Fig. 1; Schott et al., 2009). Eddies trap anomalous water masses with higher nutrients and lower oxygen content (Swart et al., 2010), induce the advection of coastal waters with high phytoplankton biomass into the offshore oceanic environment (Tew-Kai \& Marsac, 2009), and also transport sediment in suspension, as observed in the South China Sea (Zhang et al., 2014).

The upper layers of the Mozambique Channel waters are composed of Tropical Surface Water (TSW) at the surface (upper 100 to $150 \mathrm{~m}$ ), and Subtropical Surface Water (STSW) in the subsurface, from 100 to $150 \mathrm{~m}$ to about $300 \mathrm{~m}$ water depth (Fig. 2; Ullgren et al., 2012). The TSW is formed in the tropics by surface warming and excess precipitation (Ullgren et al., 2012), and is transported to the Mozambique Channel by the South Equatorial Current (SEC) (Fig. 1; Gründlingh et al., 1991). The SEC splits near $17^{\circ}$ into two branches, the north-east and south-east Madagascar Currents (NEMC and SEMC) (Fig. 1; Schott et al., 2009). The STSW is formed in the area from 25 to $35^{\circ} \mathrm{S}$ due to greater evaporation than precipitation and is characterized by a subsurface salinity maximum when it is present below the TSW (Fig. 2; Wyrtki, 1973). The permanent thermocline is mainly composed of South Indian Central Water (SICW), which is formed by sunken surface water

This article is protected by copyright. All rights reserved. 
(You, 1997). The SICW is characterized by a linear potential temperature-salinity relationship between 300 and $600 \mathrm{~m}$ water depth (Fig. 2; Ullgren et al., 2012). The sand dunes analyzed in the present study are located at water depths ranging between $200 \mathrm{~m}$ and $600 \mathrm{~m}$ and are therefore mainly under the influence of the STSW and the SICW (Fig. 2).

\section{DATA AND METHODOLOGY}

The multibeam bathymetry used for this study was acquired with Kongsberg EM122 and EM710 multibeam systems (Kongsberg Maritime, Kongsberg, Norway) during the PAMELA project surveys PTOLEMEE (2014, R/V L'Atalante; Jorry, 2014), PAMELA-MOZ01 (2014, L'Atalante; Olu, 2014) and PAMELA-MOZO4 (2015, R/V Pourquoi pas?; Jouet \& Deville, 2015), with a horizontal resolution of 5 m. Regional maps are based on GEBCO bathymetry (GEBCO_08, version 2010-09-27 http://www.gebco.net), with a 30 arc-second resolution (Fig. 1). Laser bathymetry and topography (lidar) acquired by the Litto3D program were used to illustrate the geomorphology of the Bassas da India Atoll. The backscatter obtained with the multibeam echosounder was analyzed in order to distinguish between rocky sea floor with a high reflectivity and loose sediments with low reflectivity values. This was confirmed by seismic data, a sediment sample, and video images. The seismic reflection data used in this study were acquired with a Gl-gun as seismic source and a 72-channel streamer receiver, collected during the PTOLEMEE survey. The seismic data allowed us to differentiate the sediment bodies from the underlying substrate. The thickness of the sediment body was estimated by assuming a constant sound velocity of $1500 \mathrm{~m} \mathrm{sec}^{-1}$. Submarine images were acquired with the SCAMPI camera system during the PAMELA-MOZO1 and PAMELA-MOZO4 surveys. A sediment sample (MOZ1-KGS5) was collected with a USNEL box corer on the deep terrace of Bassas da India Atoll during the PAMELA-MOZ01 survey. Grain-size distribution was measured with a Malvern Mastersizer 3000 laser diffraction particle size analyzer (Malvern Panalytical, Malvern, UK). Sand composition was determined by visual counting using a binocular microscope. The sediment sample was imaged with a FEI Quanta 200 scanning electron microscope (SEM) (Thermo Fisher

This article is protected by copyright. All rights reserved. 
Scientific, Waltham, MA, USA). Planktonic foraminifera, large benthic foraminifera typical of lagoonal systems (Amphistegina lessonii) and coral fragments were dated using radiocarbon analyses at Beta Analytic Testing Laboratory (Miami, FL, USA). Radiocarbon ages were calibrated using the Marine13 calibration curve (Reimer et al., 2013).

During the PAMELA-MOZ01 survey, one mooring (MLP4) was deployed in October 2014 on the top of Hall Bank (486 m water depth). The mooring consisted of an AANDERAA RCM11 current meter (Xylem, New York, USA), as well as temperature, oxygen and turbidity sensors situated at 30 $\mathrm{m}$ above the sea floor. This mooring was recovered in December 2015 during the PAMELA-MOZO4 survey (Fig. 1). At the same time, two other moorings (MLP3 and MLP5) were deployed east of the Bassas da India Atoll at water depths of 3392 and 4027 m, respectively. The variations in depth provided by pressure sensors at moorings MLP3 and MLP5 were used to measure tidal amplitude; such data were not available at mooring MLP4. Bottom shear stress generated by currents at the sea floor was calculated based on current data $30 \mathrm{~m}$ above the sea floor at site MLP4. At the bed interface, the bottom shear stress $(\tau)$ is mostly turbulent and can be related to the seawater density $(\rho)$ and the friction velocity $\left(u^{*}\right)$ using:

$$
\tau=\rho u^{* 2}
$$

In the boundary layer with a steady current, the turbulent velocity can be deduced from the current speed near the bottom with the relation:

$$
u^{*}=\frac{\kappa \cdot \mathrm{u}(\mathrm{z})}{\ln \left(\frac{\mathrm{z}}{\mathrm{z}_{0}}\right)}
$$

where $k$ is the Von Karman constant (equal to 0.4; Schlichting, 1962), $z_{0}$ the bottom roughness length taken here to a constant equal to $0.0035 \mathrm{~m}$ and $z$ the distance from the bottom where the current velocity $u(z)$ was measured.

This article is protected by copyright. All rights reserved. 
Additional current data down to 20 to $80 \mathrm{~m}$ above the sea floor were acquired with a hull-mounted acoustic Doppler current profiler (ADCP; $38 \mathrm{kHz}$ ) during the PTOLEMEE and PAMELA-MOZO4 surveys at Sakalaves Seamount. A conductivity-temperature-depth (CTD) sensor attached to the SCAMPI camera system allowed for measurement of temperature and salinity during the deployment of the video system. Maps of sea-level anomalies (SLA) and maps of geostrophic currents were used in order to link the observed changes in current velocity at the seamounts with mesoscale features in the Mozambique Channel. The Ssalto/Duacs SLA heights (MSLA-H) were produced and distributed by the Copernicus Marine and Environment Monitoring Service (CMEMS) (http://www.marine.copernicus.eu). The maps of SLA geostrophic currents (MSLA UV) were produced by Ssalto/Duacs and distributed by Aviso, with support from Centre National d'Etudes Spatiales (http://www.aviso.altimetry.fr/duacs/).

\section{SEDIMENT DISTRIBUTION}

\section{Sakalaves Seamount}

On the top of the Sakalaves Seamount, two elongated sediment bodies with a NNW-SSE orientation are located along a fault at 400 to $455 \mathrm{~m}$ water depth (Fig. 3A). These areas are characterized by low backscatter values compared to the rest of the seamount top, which is mainly composed of carbonate and volcanic rocks and partially covered by a thin layer of sand (Figs 3B and 4; Courgeon et al., 2016). The northern sediment body is $14.3 \mathrm{~km}$ long and $2.7 \mathrm{~km}$ wide, whereas the southern sediment body is $5.2 \mathrm{~km}$ long and $1.7 \mathrm{~km}$ wide; their maximum thickness is $25 \mathrm{~m}$ (Fig. 5). The sediment bodies have a lenticular shape and are separated by a topographic high (Fig. 5); they are plastered on the eastern part of the depression, and therefore their water depth and thickness decreases eastwards (Fig. 3). The multibeam bathymetry, the seismic data and the sea floor images show the presence of dune fields at the top of these sediment bodies (Figs 3 to 5). Based on the asymmetry, the dunes migrate in a south-east/south direction, climbing upslope. The dunes are mainly straight-crested with few bifurcations (Fig. 3C) and covered with sinuous ripples (Fig. 4).

This article is protected by copyright. All rights reserved. 
Some dunes have an arcuate morphology, especially in the western deepest part of the dune field (Fig. 3A).

\section{Bassas da India Atoll}

The south-eastern slope of the Bassas da India Atoll is characterized by the presence of two terraces located at about 200 to $240 \mathrm{~m}$ (T1) and 440 to $540 \mathrm{~m}$ (T2) water depth (Fig. 6A). The terraces and the slope transition display low backscatter values interpreted as sediment cover (Fig. 6B), except for the south-western edge of the deep terrace that is composed of volcanic rocks partially covered with carbonate sand (Fig. 4). The sediment body is about $12 \mathrm{~km}$ long and $4 \mathrm{~km}$ wide (Fig. 6). Dune fields cover large parts of the terraces (Fig. 7). Based on their asymmetrical shape, the dunes migrate towards the east/north-east on the shallow terrace and at the edge of the deep terrace, and towards the west at the foot of the slope between the two terraces (Figs 6A and 7). The morphology of the dunes at Bassas da India is highly variable. The dunes of the shallow terrace are straightcrested to slightly sinuous-crested. The dunes located at the transition between the terraces (in the upper part of the gullies) have an asymmetrical barchan morphology, with a longer southern (downslope) side (Fig. 7). On the flat area of the deep terrace the dunes have sinuous crests, with frequent bifurcations, and are covered with sinuous ripples, the crests of which are aligned parallel or sub-parallel to the dune crest (Fig. 4). The bifurcations merge into a single larger dune at the edge of the terrace where the sea floor deepens and the slope gradient increases (Figs 5 and 7).

\section{Jaguar Bank}

Jaguar Bank is affected by faults with a south-west/north-east orientation that generate bathymetric highs on their northern side (Fig. 8A). Most of the top of the Jaguar Bank has high backscatter values, which is interpreted to reflect bare rock, but some sediment bodies characterized by low backscatter values have accumulated at the foot of the faults (Fig. 8B). Carbonate and volcanic rocks are common on the top of the bank; they can be partially covered by sand with straight to slightly

This article is protected by copyright. All rights reserved. 
sinuous ripples, and the carbonates often show cavities and irregularities (Fig. 4). The northernmost sediment body has an elongated lenticular shape, is about $8 \mathrm{~km}$ long, $800 \mathrm{~m}$ wide and up to $20 \mathrm{~m}$ thick and is oriented almost parallel to the fault, at water depths ranging between 490 and $520 \mathrm{~m}$ (Figs 5 and 8). The western edge of the sediment body has an oval shape and is separated from the fault by a triangular moat (Fig. $8 \mathrm{C}$ ). The sediment body is covered by sand dunes that migrate towards the north-east (based on dune asymmetry). The dunes are mainly straight-crested in the south, but bifurcate and become more sinuous towards the north (Fig. 8C).

\section{Hall Bank}

Hall Bank has a relatively homogeneous flat top, only interrupted by a $2 \mathrm{~km}$ wide flat-bottom depression at the north-western part, which is interpreted as a volcanic crater (Courgeon et al., 2017). Sediment has only accumulated in the northern part of the depression (characterized by low backscatter) (Fig. 9). This sediment patch is covered by linguoid ripples (Fig. 4). The rest of the top of the platform is characterized by high backscatter values and is mainly composed of carbonate and volcanic rocks (Figs 4 and 9B). The carbonate rocks forming the upper northern slope of the Hall Bank are characterized by longitudinal incisions that are oriented parallel to the slope (Fig. 4).

\section{DUNE DIMENSIONS AND GRAIN SIZE}

All examined dune wavelengths range between $40 \mathrm{~m}$ and $350 \mathrm{~m}$, with heights between $0.9 \mathrm{~m}$ and $9.0 \mathrm{~m}$; they can therefore be considered as large to very large dunes (Fig. 10A; Ashley, 1990). Their dimensions differ between the different carbonate platforms, with the largest on Bassas da India Atoll (Fig. 10A). At Sakalaves Seamount the dune wavelength ( $\lambda$ ) ranges between $62 \mathrm{~m}$ and $227 \mathrm{~m}$, and the height $(h)$ between $0.9 \mathrm{~m}$ and $3.6 \mathrm{~m}$; at Bassas da India Atoll, $\lambda$ is between $54 \mathrm{~m}$ and $353 \mathrm{~m}$, and $h$ between $1.9 \mathrm{~m}$ and $9.0 \mathrm{~m}$; and at Jaguar Bank, $\lambda$ is between $40 \mathrm{~m}$ and $111 \mathrm{~m}$ and $h$ between $1.4 \mathrm{~m}$ and $5.7 \mathrm{~m}$. The dunes at Sakalaves Seamount have similar wavelengths as those on Jaguar Bank and Bassas da India Atoll, but their heights are considerably lower (Fig. 10A). Comparison of

This article is protected by copyright. All rights reserved. 
dune dimensions provides a relationship between the height and the wavelength given by $h=0.25$ $\lambda^{0.61}\left(R^{2}=0.56\right)$ for Bassas da India Atoll; $h=0.04 \lambda^{1.05}$ for Jaguar Bank $\left(R^{2}=0.67\right)$; and $h=0.13 \lambda^{0.56}$ for Sakalaves Bank $\left(R^{2}=0.20\right)$ (Fig. 10A). All the dunes studied here are below the global maximum height-spacing $(\mathrm{h}-\lambda)$ relationship compiled by Flemming $(1988,2000)$, and the dunes from Sakalaves Bank lie below the mean $\mathrm{h}-\lambda$ relationship of Flemming $(1988,2000)$ (Fig. 10A). No clear link between dune dimensions and water depth has been observed (Fig. 11). Nevertheless, the maximum wavelength of all the dunes and the height of the dunes at Bassas da India Atoll seem to decrease with increasing slopes (Fig. 11B).

The sediment sample collected in a trough of a dune on the deep terrace of Bassas da India Atoll is mainly composed of medium sand ( $95 \%$ sand, $3 \%$ silt and $2 \%$ clay), with a mean grain-size of $453 \mu \mathrm{m}$ (Figs 10 and 12A). According to Flemming et al. (2000), the maximum dune dimensions that can be achieved for those grain-sizes would be a wavelength of about $350 \mathrm{~m}$ and a height of about $20 \mathrm{~m}$ (Fig. 10A). Some dunes from Bassas da India Atoll appear to have reached their maximum wavelength but were apparently unable to grow to their maximum height (Fig. 10A). The sand is calcium carbonate, mainly composed of amorphous carbonate fragments (59\%), which are probably fragments of corals and algae. The other main components of the sand are planktonic foraminifera ( $23 \%)$, benthic foraminifera (12\%) and gastropods ( $5 \%$; mainly pteropods) (Fig. 12B). The age of the sand components differs strongly depending on the type of sediment: the age of planktonic foraminifera is $13895 \pm 165 \mathrm{cal} \mathrm{yr} \mathrm{BP}$, the age of the coral fragments is $33265 \pm 395 \mathrm{cal} \mathrm{yr}$ BP and the age of the shallow-water benthic foraminifers Amphistegina lessonii is $42393 \pm 598 \mathrm{cal} \mathrm{yr}$ BP.

\section{BOTTOM CURRENTS AT THE ISOLATED CARBONATE PLATFORMS}

The mooring MLP4 measured current velocity, temperature, oxygen and turbidity at $30 \mathrm{~m}$ above the top of Hall Bank between October 2014 and December 2015 (Fig. 9) and thus recorded the general circulation patterns affecting the group of seamounts of the central part of the Mozambique

This article is protected by copyright. All rights reserved. 
Channel, including Jaguar Bank and Bassas da India Atoll. Sakalaves Seamount is more distant and therefore thought to be affected by a different current regime (Fig. 1). The mean current speed recorded at mooring site MLP4 was $14 \mathrm{~cm} \mathrm{sec}^{-1}$ and the maximum speed reached $57 \mathrm{~cm} \mathrm{sec}^{-1}$ on 20 April 2015 (Fig. 13). The current direction is mainly north-west, with some large-scale changes in direction related to the presence of anticyclonic eddies near the mooring site (Fig. 14A). The high frequency variability is related to the tidal components M2 (period of $12.42 \mathrm{~h}$ ) and M4 (period of $6.21 \mathrm{~h})$ (Fig. 14B). This daily variability can be observed in the velocity data; the mean meridional component is often positive (northward flow), but it shows a strong variability at high frequencies decreasing down to zero or even to negative values (southward flow) (Fig. 13). A similar pattern of reversing currents is observed in the zonal component of the velocity: the mean values are negative (westward flow) but increasing to zero or to positive values (eastward) at tidal frequencies (Fig. 13). These changes in current direction and intensity are correlated with changes in temperature and turbidity. Peaks in turbidity correspond to a decrease in temperature and in current speed (Fig. 15). The peaks in turbidity occur between high tide and low tide, corresponding to the period of minimum current speed (Fig. 15).

Temperature fluctuations and variations of the oxygen content follow a similar evolution over time, with fast drops in temperature and oxygen content in December 2014 and March 2015 (Fig. 13). The SICW is characterized by a peak in oxygen content at 400 to $600 \mathrm{~m}$ water depth. Below that depth, oxygen content and temperature decrease (Fig. 2B). The changes in temperature and oxygen recorded at the mooring site MLP4 (642 $\mathrm{m}$ water depth) may be related to the vertical displacement of the maximum oxygen zone. The turbidity measurements here do not show any relationship with the above-mentioned parameters (Fig. 13). However, major drops in temperature and oxygen seem to be related to the major changes in current direction (Fig. 13).

Sea-level anomaly data of the Mozambique Channel show that changes in current direction recorded by mooring MLP4 between the end of February 2015 and mid-May 2015 were related to the presence of an anticyclonic eddy near Hall Bank. On 25 February 2015, the eddy was located

This article is protected by copyright. All rights reserved. 
north of the bank, but it had not reached the bank itself yet (Fig. 16). Soon after this date, a change in the velocity direction and an increase in speed were recorded at the mooring site (Fig. 13). The shape of the eddy seemed to be affected by the topographic high that contains this group of islands and seamounts (Fig. 16). On 20 April 2015, Hall Bank was under the influence of the edge of the eddy, where the geostrophic currents are the strongest (Fig. 16). This was coincident with the day when the most intense currents of $57 \mathrm{~cm} \mathrm{sec}^{-1}$ were detected (Fig. 13). On 15 May 2015, the anticyclonic eddy had already moved south of Hall Bank, and the current speed recorded at MLP4 decreased (Figs 13 and 16).

Not all of the anticyclonic eddies that pass through the Mozambique Channel affect the islands and seamounts in the central part of the channel, because some eddies move closer to the Mozambican continental slope, for example the northern anticyclone shown in Fig. 16. In contrast, the Sakalaves Seamount is much more often affected by eddies due to its location in the narrowest part of the Mozambique Channel (Fig. 16). The data from the hull-mounted ADCP show southward directed currents, in agreement with the southward migration of the dunes (Fig. 3). During the PAMELA-MOZO4 survey, the currents near the sea floor in the northern part of the Sakalaves Seamount oscillated between $24 \mathrm{~cm}$ and $36 \mathrm{~cm} \mathrm{sec}^{-1}$ north of the dune field, and between $18 \mathrm{~cm}$ and $19 \mathrm{~cm} \mathrm{sec}^{-1}$ at the dune field (Fig. 3A). During the PTOLEMEE survey bottom currents ranged between $17 \mathrm{~cm}$ and $22 \mathrm{~cm} \mathrm{sec}^{-1}$ at the dune field, and between $21 \mathrm{~cm}$ and $26 \mathrm{~cm} \mathrm{sec}^{-1}$ at the zone that separates the dune field from the fault (Fig. 3A).

\section{DISCUSSION}

\section{Dune activity}

Dune migration rates could not be estimated from differential bathymetric data and dune crest displacements due to the lack of comparative high-resolution multibeam bathymetry acquired at different times. However, the height-wavelength $(h-\lambda)$ relationship and the height/wavelength $(h / \lambda)$ ratio of the dunes can provide information about their activity (Flemming, 1980; Dyer, 1986). The 
dunes from Sakalaves Seamount lie below the mean $h-\lambda$ relationship proposed by Flemming (1988, 2000) (Fig. 10A) and their $h / \lambda$ ratio is below 0.03 (Fig. 10B), suggesting that these dunes were no longer active during the surveys and probably for some time before the present observation (Flemming, 1980; Dyer, 1986). The crests of the dunes in Sakalaves may have become rounded due to prolonged weak currents that are able to transport sediment by ripple migration, but not by dune migration. Therefore, sediment would be winnowed from the crests into the troughs, causing a reduction in height but not in wavelength (cf. Flemming, 2013). Alternatively, the currents may have been temporarily high enough for upper plane-bed transport to take place. By contrast, most of the Bassas da India Atoll and Jaguar Bank dunes plot above the mean $h-\lambda$ relationship, and their $h / \lambda$ ratio is above 0.03 (Fig. 10), indicating that these dunes are active (Flemming, 1980; Dyer, 1986).

The $h-\lambda$ relationships of the dunes also provides information about sediment starvation. The regression line of the dune size values from Bassas da India Atoll shows that at wavelengths larger than around $100 \mathrm{~m}$, the dunes do not reach their maximum height (Fig. 10A). This trend could be caused by progressive sediment starvation. The largest dunes at Bassas da India Atoll are located at the edge of the terrace where the slope is the steepest (Figs 5 and 7). This sediment starvation may be caused by enhanced downslope gravitational sediment transport at the edge of the terrace. By contrast, the largest dunes from Jaguar Bank almost reach their maximum height (Fig. 10A), suggesting that sediment is readily available in this dune field.

The morphometric analysis of the dunes shows no clear relationship between dune dimensions and water depth (Fig. 11), and therefore the dune fields do not seem to be related to a specific water mass or water mass interface. Nevertheless, the wavelength and height of the dunes from Bassas da India Atoll seem to decrease with increasing basement slope (Fig. 11B). The growth and migration of dunes upslope may be limited by downslope transport.

The long-term (weekly to monthly) variability of the turbidity at Hall Bank does not seem to be related to current velocity, temperature or oxygen content (Fig. 13), and could be caused by nonhydrodynamic processes such as productivity. However, the semi-diurnal variability of the turbidity

This article is protected by copyright. All rights reserved. 
is related to current velocity and temperature (Fig. 15). Between low tide and high tide bottomcurrent intensity increases (flood current). For instance, on 2 May 2015 the bottom shear stress during the flood current increased from almost zero to $0.2 \mathrm{~N} \mathrm{~m}^{-2}$. These periods of strong currents are coincident with turbidity minima (Fig. 15). Strong currents near the sea floor may keep the sediment in suspension and transport it downcurrent. However, when the currents slow down (slack currents), sediment particles start to settle, increasing the turbidity at the mooring site. Due to the tide-generated variability in the current velocity, erosion and deposition may occur repeatedly. During periods of intense bottom currents, such as at the end of April 2015 (Fig. 13), even the minimum velocity stayed above $10 \mathrm{~cm} \mathrm{sec}^{-1}$ (mean values about $30 \mathrm{~cm} \mathrm{sec}^{-1}$ ), and the bottom shear stress above $0.04 \mathrm{~N} \mathrm{~m}^{-2}$ (mean values about $0.2 \mathrm{~N} \mathrm{~m}^{-2}$ ). Based on the Shields curve (Soulsby, 1997), the critical shear stress for erosion of fine carbonate sand in the study area would be $0.17 \mathrm{~N} \mathrm{~m}^{-2}$. Periods of intense current activity could therefore almost continuously erode fine sand, which is consistent with the absence of large sediment accumulations on the top of Hall Bank (Fig. 9). Using the same curve, the critical shear stress for sediment collected in a dune trough on the deep terrace of Bassas da India ( $D 50=400 \mu \mathrm{m}$ ) would be $0.23 \mathrm{~N} \mathrm{~m}^{-2}$. Bottom shear stress calculated from current data at MLP4 mooring frequently exceeded this critical value (Fig. 13), confirming that the recorded current data would be strong enough to transport the sampled material, and thus also supporting the interpretation that the dunes at Bassas da India Atoll are still active. Although bottom currents are not constantly strong, sand can probably still be transported on the top of the platforms during intense current events. The sand dunes on the carbonate platforms show a constant direction of migration, and there is no evidence of sand recycling within a single sediment body. On the Bassas da India terrace, however, some dunes migrate in opposite directions, although they are located at different depths (Figs 6 and 7). These different groups of dunes migrate independently alongslope (Fig. 7). A portion of the sand moved by dunes may be transported to the edge of the platform and subsequently fall downslope through gullies and canyons, which are often present around the platforms (Figs 3, 6, 8 and 9). These processes could also feed the turbidite systems observed at the 
foot of the seamount slopes (Counts et al., 2018). A similar sand transfer from dune fields to the deep-sea through canyons has been previously observed in the south-east African margin (Ramsay et al., 1996) and in the south-east Brazilian margin (Viana \& Faugères, 1998).

The Sakalaves Seamount is located in the narrowest part of the Mozambique Channel, in the main corridor of anticyclonic eddies and rings (Halo et al., 2014). Therefore, compared to the carbonate platforms of the southern central zone of the Mozambique Channel, the Sakalaves Seamount could be affected more often by high intensity currents related to eddies. The present currents on Sakalaves may be too strong for the complete development of the dunes, which currently may be under erosion, explaining their low $h / \lambda$ ratio (Fig. 10B). The location of the sediment body east of the north-south trending fault containing dunes oblique to the fault with crests oriented in a north-east/south-west direction is consistent with the observed south/southeast flow (Fig. 3A). Similar dunes have been observed in the Messinian Strait: migrating upslope with a deflected orientation, with $h=1.5$ to $5 \mathrm{~m}$ and $\lambda=60$ to $120 \mathrm{~m}$ (Droghei et al., 2016). The formation of these bedforms in the Messinian Strait was attributed to internal solitary waves generated by the interaction of tidal currents with the sill of the Messinian Strait (Droghei et al., 2016). Internal waves are frequently generated by tidal flow over seamounts (Zhang et al., 2017). Da Silva et al. (2009) showed that internal solitary waves can be formed on carbonate platforms in the Mozambique Channel. These processes could affect the Sakalaves dunes and may be responsible for shaping their morphology. A north-south trending fault atop the Sakalaves Seamount generates a 85 to $125 \mathrm{~m}$ high escarpment (Fig. 3), creating a difference in relief that may favour the formation of internal waves that mobilize and transfer sand from the top of the fault escarpment to the dune field. Moreover, when the internal waves propagate above the sediment bodies, they may modify the dune morphology by moving sediment from the crest to the trough of the dune and consequently reducing the dune height. In Hall Bank and Bassas da India Atoll the dune migration is parallel to the bathymetric contours and is more similar to dunes related to tidal currents (Franzetti et al., 2013) and geostrophic flows (King et al., 2014).

This article is protected by copyright. All rights reserved. 


\section{Origin of the sand}

Among the studied carbonate platforms, Bassas da India Atoll is the only one where shallow-water carbonate production is active. Bassas da India Atoll has a fringing reef that completely encircles a lagoon (Fig. 6). The sand sample collected in a dune of the Bassas da India deep terrace contains coral fragments and shallow-water large benthic foraminifera (Amphisorus hemprichii, Amphistegina lessonii and Neorotalia calcar, among others), indicating that the dunes are in part composed of sand shed from the platform top (Fig. 12B). Dunes are also composed of sediment particles of pelagic origin, such as planktonic foraminifera and pteropods (Fig. 12B). Although the Bassas da India Atoll is still active, the shallow-water benthic foraminifers collected on the terrace were dated at $42393 \pm 598 \mathrm{cal}$ yr Bp. At that time the sea-level was about $60 \mathrm{~m}$ below present (Spratt \& Lisiecki, 2016), and the top of the platform was subaerially exposed. Therefore, the benthic foraminifera in the dune sands were probably derived from the edges of the platform. The presence of these benthic foraminifera and of planktonic foraminifera dated at $13895 \pm 165$ cal yr BP shows that the downslope sand transfer was not instantaneous and continuous. Sediment may have been stored in shallower depocentres for extended periods of time before being transported downslope by extraordinary events.

In contrast to Bassas da India, the Sakalaves Seamount, Hall Bank and Jaguar Bank drowned during the Upper Miocene-Lower Pliocene (Courgeon et al., 2017). Therefore, it is very unlikely that the observed sediment bodies are the remains of sand produced when the platforms were active and close to the sea surface. Moreover, since the dunes of each field are migrating in the same direction, the sediment is probably continuously being transported in the direction of migration of the dunes towards the edges of the platform. Therefore, little sand may be recycled within each dune field. However, these sediment bodies are usually located in depressions (Fig. 5), and thus the lower part of the sediment body may be more stable as it is trapped within the depression. The upper part is likely more dynamic. Although no samples of these dunes were collected, images of the

This article is protected by copyright. All rights reserved. 
sea floor show that sand is mainly bioclastic in origin (Fig. 4). Carbonate rocks observed at the same locality show evidence of erosion. Scours, for instance, are evident on the carbonate rocks that form the north-eastern flank of Hall Bank (Fig. 4). These scours are parallel to the slope and are probably generated by bottom currents (Fig. 4). The source of sand in the dunes may therefore be submerged lithified carbonates that have been eroded by oceanic currents, as well as pelagic sediment. The carbonate rocks on these seamounts are weakly cemented and their different components (for example, foraminifera and coral fragments) may easily become detached from the matrix, especially as post-drowning pelagic cementation is generally weaker than that formed in shallow-water (Courgeon et al., 2016, 2017). Carbonate rocks are much more susceptible to erosion than volcanic rocks (Chorley et al., 1984; Meybeck, 1987; Probst, 1992), which may explain why dunes are only composed of carbonates. Moreover, the sediment bodies are always located close to faults. The collapse of the fault escarpment generates the formation of blocks as observed at Sakalaves (Fig. 4). Carbonate rocks affected by faulting and rock fall may be weaker, and thus more susceptible to submarine erosion. The recent activity of the normal faults and their associated seismicity (Deville et al., 2018), may have fractured these carbonates and thus favoured sand production. Continuous erosion of the carbonates after the drowning of the platform may have therefore important implications for carbonate preservation in areas of intense oceanic circulation. In addition to the sand originating from the erosion of carbonate rocks, part of the sand is of pelagic origin (planktonic foraminifera and pteropods; Fig. 12B), which is produced continuously above drowned platforms.

\section{Sand dunes in deep settings: a type of contourite}

Sandbanks are large-scale bed forms parallel to the flow often generated by tidal or wind-driven currents and are commonly found in coastal areas and on the continental shelf (Dyer \& Huntley, 1999). Sandbank is thus a broad term mainly based on the geomorphology of the sediment deposit, without any depth restrictions. On the other hand, the term contourite is defined as: "sediments deposited or substantially reworked by the persistent action of bottom currents" (Stow et al., 2002;

This article is protected by copyright. All rights reserved. 
Rebesco, 2005, 2014). 'Contourite' has commonly been used for deep-sea settings, in order to differentiate current-related deposits from deposits related to gravity processes or pelagic sedimentation (Faugères et al., 1999; Rebesco et al., 2014), although contourites have also been identified in shallower zones such as the continental shelf and the upper slope (Viana et al., 1998; Verdicchio \& Trincardi, 2008). Despite the fact that most of the recognized contourites correspond to large muddy mounded sediment bodies (sediment drift; Rebesco et al., 2014), they can also be composed of sand, and hence be transformed into sand dunes by suitable currents (Viana, 2001; Hernández-Molina et al., 2017). Therefore, sediment drifts can form under weak or strong hydrodynamic conditions, resulting in muddy or sandy deposits respectively. As in the present study, isolated accumulations of sand may develop in deep settings where strong currents may generate dunes at their tops (Figs 3, 5 and 8). Such sediment bodies at the top of drowned platforms have lenticular shapes in cross-section, thinning down towards the edges of the sediment bodies, and are often separated from sea floor escarpments by moats (Fig. 5). This geometry is very similar to sandbanks (Franzetti et al., 2015) and to plastered drifts (muddy contourites), which typically have an oval shape in plan view and a convex shape in cross-section (Miramontes et al., 2018). The resolution of the seismic data used for the present study does not reveal the internal architecture of the sediment bodies, which prevents a more specific classification. Therefore, more detailed studies on deep marine sand bodies and sand dunes are necessary to better understand their formation and evolution, as well as to compare them with shallow water sandbanks and sand dunes.

\section{CONCLUSIONS}

Fields of submarine sand dunes were identified on drowned carbonate platforms (Sakalaves Seamount, Bassas da India Atoll and Jaguar Bank) in the Mozambique Channel at depths ranging from 200 to $600 \mathrm{~m}$. The main conclusions of this study can be summarized as follows:

1 The dunes are composed of medium carbonate sand; they are large to very large, with wavelengths of 40 to $350 \mathrm{~m}$ and heights of 0.9 to $9.0 \mathrm{~m}$. No relationship has been observed

This article is protected by copyright. All rights reserved. 
between dune size and water depth, hence the formation of dunes does not seem to be related to any specific water mass or water-mass interface. The dunes on Bassas da India Atoll and Jaguar Bank are active since their height-wavelength $(h-\lambda)$ relationship lies above the global mean power law correlation and their $\mathrm{h} / \lambda$ ratios above 0.03 . The dunes on Sakalaves Bank, by contrast, have smaller heights, with $h-\lambda$ relationships below the mean trend and $h / \lambda$ ratios below 0.03 ; this indicates that they had been inactive for an unknown period of time before their discovery.

2 Dune migration seems to be unidirectional in each dune field, with little sand being recycled, suggesting continuous formation of carbonate sand and export to the deep basin. In the Bassas da India Atoll shallow-water carbonate sand is still being produced today. However, the Sakalaves Seamount, and the Hall and Jaguar Banks were drowned since the Upper Miocene-Lower Pliocene. In the Mozambique Channel oceanic currents are very intense and may hence be able to erode drowned carbonates, generating carbonate sand at great depths and supplying sand to the dunes. All of the sediment bodies are located in depressions related to fault escarpments. Faulted carbonate rocks, post-drowning carbonate rocks with weak cementation and pelagic sediment are the most probable origin of the sands composing the sediment bodies of the drowned platforms.

3 The current measurements from hull-mounted acoustic Doppler current profiler (ADCP) at Sakalaves Seamount and from a mooring on the Hall Bank showed that bottom currents are very strong; 17 to $36 \mathrm{~cm} \mathrm{sec}^{-1}$ on the Sakalaves Seamount, and mean values of $14 \mathrm{~cm} \mathrm{sec}^{-1}$ and maximum values of $57 \mathrm{~cm} \mathrm{sec}^{-1}$ on the Hall Bank, compatible with dune formation. The intensity of the currents is highly variable; the short-term variability is caused by tides and the long-term variability is related to the presence of anticyclonic eddies near the seamounts.

This article is protected by copyright. All rights reserved. 


\section{ACKNOWLEDGEMENTS}

We thank the Captain and the crew of the PTOLEMEE and PAMELA-MOZ01 surveys onboard the $R / V$ L'Atalante and the PAMELA-MOZO4 survey onboard the $R / V$ Pourquoi pas?. The oceanographic surveys PTOLEMEE, PAMELA-MOZO1 and PAMELA-MOZO4, as well as Elda Miramontes' PostDoctoral fellowship were co-funded by TOTAL and IFREMER as part of the PAMELA (Passive Margin Exploration Laboratories) scientific project. The PAMELA project is a scientific project led by Ifremer and TOTAL in collaboration with Université de Bretagne Occidentale, Université Rennes 1, Université Pierre and Marie Curie, CNRS and IFPEN. John W. Counts' Post-Doctoral fellowship was co-funded by the "Laboratoire d'Excellence" LabexMER (ANR-10-LABX-19) and a grant from the French government under the program "Investissements d'Avenir". The research of F. J. Hernández-Molina was conducted in the framework of the "Drifters Research Group" of the Royal Holloway University of London (UK). We are very grateful to C. Betzler, as Associate Editor of this manuscript, and B. Flemming and A. Viana, as reviewers, for their suggestions, which helped us to improve the manuscript considerably.

\section{REFERENCES}

Allen, J.R.L. (1968) The nature and origin of bed-form hierarchies. Sedimentology, 10, 161-182.

Ashley, G.M. (1990) Classification of large-scale subaqueous bedforms: a new look at an old problem. Journal of Sedimentary Petrology, 60, 160-172.

Betzler, C., Hübscher, C., Lindhorst, S., Reijmer, J.J., Römer, M., Droxler, A.W., Fürstenau, J. and Lüdmann, T. (2009) Monsoon-induced partial carbonate platform drowning (Maldives, Indian Ocean). Geology, 37, 867-870.

Bøe, R., Skarðhamar, J., Rise, L., Dolan, M.F.J., Bellec, V.K., Winsborrow, M., Skagseth, $\varnothing$., Knies, J., King, E.L., Walderhaug, O., Chang, S., Buenz, S. and Miniert, J. (2015) Sandwaves and sand transport on the Barents Sea continental slope offshore northern Norway. Marine and Petroleum Geology, 60, 34-53.

This article is protected by copyright. All rights reserved. 
Campbell, C. and Mosher, D.C. (2016) Geophysical evidence for widespread Cenozoic bottom current activity from the continental margin of Nova Scotia, Canada. Marine Geology, 378, 237-260.

Capella, W., Hernández-Molina, F.J., Flecker, R., Hilgen, F.J., Hssain, M., Kouwenhoven, T.J., van Oorschot, M., Sierro, F.J., Stow, D.A.V., Trabucho-Alexandre, J., Tulbure, M.A., de Weger, W., Yousfi, M.Z. and Krijgsman, W. (2017) Sandy contourite drift in the late Miocene Rifian Corridor (Morocco): Reconstruction of depositional environments in a foreland-basin seaway. Sedimentary Geology, 355, 31-57.

Chorley, R.J., Schumm, S.A. and Sugden, D.E. (1984) Geomorphology. Methuen, London, 605 pp.

Coffin, M.F. and Rabinowitz, P.D. (1987) Reconstruction of Madagascar and Africa: evidence from the Davies Fracture Zone and Western Somali Basin. Journal of Geophysical Research: Solid Earth, 92, 9385-9406.

Counts, J.W., Jorry, S.J., Leroux, E., Miramontes, E. and Jouet, G. (2018) Sedimentation adjacent to atolls and volcano-cored carbonate platforms in the Mozambique Channel (SW Indian Ocean). Marine Geology, 404, 41-59.

Courgeon, S., Jorry, S.J., Camoin, G.F., BouDagher-Fadel, M.K., Jouet, G., Révillon, S., Bachèlery, P., Pelleter, E., Borgomano, J., Poli, E. and Droxler, A.W. (2016) Growth and demise of Cenozoic isolated carbonate platforms: New insights from the Mozambique Channel seamounts (SW Indian Ocean). Marine Geology, 380, 90-105.

Courgeon, S., Jorry, S.J., Jouet, G., Camoin, G., BouDagher-Fadel, M.K., Bachèlery, P., Caline, B., Boichard, R., Révillon, S., Thomas, Y., Thereau, E. and Guérin, C. (2017) Impact of tectonic and volcanism on the Neogene evolution of isolated carbonate platforms (SW Indian Ocean). Sedimentary Geology, 355, 114-131.

Courgeon, S., Bachèlery, P., Jouet, G., Jorry, S., Bou, E., BouDagherFadel, M.K., Révillon, S., Camoin, G. and Poli, E. (2018) The Offshore East African Rift System: New insights from the Sakalaves Seamounts (Davie Ridge, SW Indian Ocean). Terra Nova, 30, 380-388.

This article is protected by copyright. All rights reserved. 
Da Silva, J.C.B., New, A.L., and Magalhaes, J.M. (2009) Internal solitary waves in the Mozambique Channel: Observations and interpretation. Journal of Geophysical Research: Oceans, 114. Available at: http://dx.doi.org/ 10.1029/2008JC005125

de Ruijter, W.P.M., Ridderinkhof, H., Lutjeharms, J.R.E., Schouten, M.W. and Veth, C. (2002) Observations of the flow in the Mozambique Channel. Geophysical Research Letters, 29. Available at: http://dx.doi.org/10.1029/2001GL013714.

Deville, E., Marsset, T., Courgeon, S., Jatiault, R., Ponte, J.-P., Thereau, E., Jouet, G., Jorry, S. and Droz, L. (2018) Active fault system across the oceanic lithosphere of the Mozambique Channel: Implications for the Nubia-Somalia southern plate boundary. Earth and Planetary Science Letters, $502,210-220$.

DiMarco, S.F., Chapman, P., Nowlin, W.D. Jr, Hacker, P., Donohue, K., Luther, M., Johnson, G.C. and Toole, J. (2002) Volume transport and property distributions of the Mozambique Channel. DeepSea Res II (Topical Studies in Oceanography), 49, 1481-1511.

Droghei, R., Falcini, F., Casalbore, D., Martorelli, E., Mosetti, R., Sannino, G., Santoreli, R. and Chiocci, F. L. (2016) The role of Internal Solitary Waves on deep-water sedimentary processes: the case of up-slope migrating sediment waves off the Messina Strait. Scientific Reports, 6, 36376.

Dyer, K.R. (1986) Coastal and Estuarine Sediment Dynamics. Wiley \& Sons, Chichester, England, 358 pp.

Dyer, K.R. and Huntley, D.A. (1999) The origin, classification and modelling of sand banks and ridges. Continental Shelf Research, 19, 1285-1330.

Faugères, J.C., Stow, D.A., Imbert, P. and Viana, A. (1999) Seismic features diagnostic of contourite drifts. Marine Geology, 162, 1-38.

Flemming, B.W. (1980) Sand transport and bedform patterns on the continental shelf between Durban and Port Elizabeth (southeast African continental margin). Sedimentary Geology, 26, 179205.

This article is protected by copyright. All rights reserved. 
Flemming, B. W. (1988) Zur Klassifikation subaquatischer, strömungstransversaler Transportkörper. Bochumer Geologische und Geotechnische Arbeiten, 29, 93-97.

Flemming, B.W. (2000) The role of grain size, water depth and flow velocity as scaling factors controlling the size of subaqueous dunes. In: Marine Sediment Wave Dynamics (Eds A. Trentesaux and T. Garlan), Proceedings of International Workshop held in Lille, France, 23-24 March 2000. University of Lille 1, Lille, pp. 55-60.

Flemming, B.W. (2013) Comment on "Large-scale bedforms along a tideless outer shelf setting in the western Mediterranean" by Lo lacono et al.(2010) in Continental Shelf Research vol 30, pp. 18021813. Continental Shelf Research, 52, 203-207.

Flemming, B.W. and Kudrass, H. (2018) Large dunes on the outer shelf off the Zambezi Delta, Mozambique: evidence for the existence of a Mozambique Current. Geo-Marine Letters, 38, 95105.

Franzetti, M., Le Roy, P., Delacourt, C., Garlan, T., Cancouët, R., Sukhovich, A. and Deschamps, A. (2013) Giant dune morphologies and dynamics in a deep continental shelf environment: example of the banc du four (Western Brittany, France). Marine Geology, 346, 17-30.

Franzetti, M., Le Roy, P., Garlan, T., Graindorge, D., Sukhovich, A., Delacourt, C. and Le Dantec, N. (2015) Long term evolution and internal architecture of a high-energy banner ridge from seismic survey of Banc du Four (Western Brittany, France). Marine Geology, 369, 196-211.

Gordon, A.L. (1986) Inter-ocean exchange of thermocline water. Geophysical Research Letters, 91, $5037-5046$.

Gründlingh, M.L., Carter, R.A. and Stanton, R.C. (1991) Circulation and water properties of the southwest Indian Ocean, spring 1987. Progress in Oceanography, 28, 305-342.

Halo, I., Backeberg, B., Penven, P., Ansorge, I., Reason, C. and Ullgren, J.E. (2014) Eddy properties in the Mozambique Channel: A comparison between observations and two numerical ocean circulation models. Deep Sea Research Part II: Topical Studies in Oceanography, 100, 38-53.

This article is protected by copyright. All rights reserved. 
Hanquiez, V., Mulder, T., Lecroart, P., Gonthier, E., Marchès, E. and Voisset, M. (2007) High resolution seafloor images in the Gulf of Cadiz, Iberian margin. Marine Geology, 246, 42-59.

Hernández-Molina, F.J., Ercilla, G., Casas, D., Roque, C., Stow, D.A.V. and MOWER Cruise team (2016) Larger Morphological Sea-Floor Features and Bedforms Associated to the Mediterranean Outflow Water in the Gulf of Cadiz. In: MARID 2016. Fifth International Conference on Marine and River Dune Dynamics (Eds K.J.J. Van Landeghem, T. Garlan and J.H. Baas), Caernarfon, United Kingdom, 4-6 April 2016. Bangor University and SHOM. ISBN: 978-2-11-128417-3 (Abstract volume, 216 pp.).

Hernández-Molina, F.J., Campbell, S., Badalini, G., Thompson, P., Walker, R., Soto, M., Conti, B., Preu, B., Thieblemont, A., Hyslop, L., Miramontes, E. and Morales, E. (2017) Large bedforms on contourite terraces: Sedimentary and conceptual implications. Geology, 46, 27-30.

Jorry, S. (2014) PTOLEMEE cruise, RV L'Atalante. Available at : http://dx.doi.org/10.17600/14000900. Jouet, G. and Deville, E. (2015) PAMELA-MOZO4 cruise, RV Pourquoi pas?. Available at: http://dx.doi.org/10.17600/15000700.

Kenyon, N.H., Akhmetzhanov, A.M. and Twichell, D.C. (2002) Sand wave fields beneath the Loop Current, Gulf of Mexico: reworking of fan sands. Marine Geology, 192, 297-307.

King, E.K., Bøe, R., Bellec, V., Rise, L., Skarðhamar, J., Ferre, B. and Dolan, M. (2014) Contour current driven continental slope-situated sandwaves with effects from secondary current processes on the Barents Sea margin offshore Norway. Marine Geology, 353, 108-127.

Lonsdale, P. and Malfait, B. (1974) Abyssal dunes of foraminiferal sand on the Carnegie Ridge. Geological Society of America Bulletin, 85, 1697-1712.

Lüdmann, T., Kalvelage, C., Betzler, C., Fürstenau, J. and Hübscher, C. (2013) The Maldives, a giant isolated carbonate platform dominated by bottom currents. Marine and Petroleum Geology, 43, $326-340$.

Lutjeharms, J.R.E. (2006) The Agulhas Current, Vol. 1. Springer-Verlag, Berlin, 329 pp.

This article is protected by copyright. All rights reserved. 
Lutjeharms, J.R.E., Biastoch, A., van der Werf, P.M., Ridderinkhof, H. and de Ruijter, W.P.M. (2012)

On the discontinuous nature of the Mozambique current. South African Journal of Science, 108, 01-05.

Mahanjane, E.S. (2014) The Davie Fracture Zone and adjacent basins in the offshore Mozambique Margin-A new insights for the hydrocarbon potential. Marine and Petroleum Geology, 57, 561571.

Meybeck, M. (1987) Global chemical weathering of surficial rocks estimated from river dissolved loads. American Journal of Science, 287, 401-428.

Miramontes, E., Garziglia, S., Sultan, N., Jouet, G. and Cattaneo, A (2018) Morphological control of slope instability in contourites: a geotechnical approach. Landslides, 15, 1085-1095.

Mutti, E., Cunha, R.S., Bulhoes, E.M., Arienti, L.M. and Viana, A. (2014) Contourites and turbidites of the Brazilian marginal basins (adapted from oral presentation at AAPG Annual Convention and Exhibition, Houston, Texas, 6-9 April): American Association of Petroleum Geologists Search and Discovery Article 51069, 46 p. Available at: http://www .searchanddiscovery .com /documents /2015/51069mutti /ndx mutti.pdf.

Olu, K. (2014) PAMELA-MOZ01 cruise, RV L'Atalante. Available at: http://dx.doi.org/10.17600/14001000.

Probst, J.L. (1992) Géochimie et hydrologie de l'érosion continentale. Mécanismes, bilan global actuel et fluctuations au cours des 500 derniers millions d'années, Sciences Géologiques Mémoires, Ed. Univ. Strasbourg, 94, 167 p.

Quartly, G.D., de Cuevas, B.A. and Coward, A.C. (2013) Mozambique Channel eddies in GCMs: a question of resolution and slippage. Ocean Modelling, 63, 56-67.

Ramsay, P.J., Smith, A.M. and Mason, T.R. (1996) Geostrophic sand ridge, dune fields and associated bedforms from the Northern KwaZulu-Natal shelf, south-east Africa. Sedimentology, 43, 407-419.

Rebesco, M. (2005) Contourites. In: Encyclopedia of Geology (Eds. R. C. Selley, L. R. M. Cocks, I. R. Plimer). Elsevier, Oxford, pp. 513-527.

This article is protected by copyright. All rights reserved. 
Rebesco, M. (2014) Contourites. In: Reference Module in Earth Systems and Environmental Sciences (Ed. S.A. Elias), Elsevier. Available at: http://dx.doi.org/10.1016/B978-0-12-409548-9.02964-X.

Rebesco, M., Hernández-Molina, F.J., Van Rooij, D. and Wåhlin, A. (2014) Contourites and associated sediments controlled by deep-water circulation processes: state-of-the-art and future considerations. Marine Geology, 352, 111-154.

Reeder, D.B., Ma, B.B. and Yang, Y.J. (2011) Very large subaqueous sand dunes on the upper continental slope in the South China Sea generated by episodic, shoaling deepwater internal solitary waves. Marine Geology, 279, 12-18.

Reimer, P.J., Bard, E., Bayliss, A., Beck, J.W., Blackwell, P.G., Ramsey, C.B., Buck, C.E., Cheng, H., Edwards, R.L., Friedrich, M., Grootes, P.M., Guilderson, T.P., Haflidason, H., Hajdas, I., Hatte, C., Heaton, T.J., Hoffmann, D.L., Hogg, A.G., Hughen, K.A., Kaiser, K.F., Kromer, B., Manning, S.W., Niu, M., Reimer, R.W., Richards, D.A., Scott, E.M., Southon, J.R., Staff, R.A., Turney, C.S.M. and van der Plicht, J. (2013) IntCal13 and Marine13 radiocarbon age calibration curves 0-50,000 years cal BP. Radiocarbon 55, 1869-1887.

Schlichting, H. (1962) Boundary Layer Theory. 6th ed., McGraw-Hill, New York, 744 pp.

Schott, F.A., Xie, S.-P. and McCreary, J.P. Jr. (2009) Indian Ocean circulation and climate variability. Reviews of Geophysics, 47, RG1002.

Schouten, M.W., de Ruijter, W.P.M., van Leeuwen, P.J. and Dijkstra, H.A. (2002) An oceanic teleconnection between the equatorial and southern Indian Ocean. Geophysical Research Letters, 29. Available at: http://dx.doi.org/10.1029/2001GL014542.

Soulsby, R. (1997) Dynamics of Marine Sands: A Manual for Practical Applications. Thomas Telford, London, $253 \mathrm{pp}$.

Spratt, R.M. and Lisiecki, L.E. (2016) A Late Pleistocene sea level stack. Climate of the Past, 12, 10791092.

Stow, D.A.V., Kahler and G., Reeder, M. (2002) Fossil contourites: type example from an Oligocene palaeoslope system, Cyprus. In: Deep-water Contourite Systems: Modern Drifts and Ancient 
Series, Seismic and Sedimentary Characteristics (Eds D. A. V. Stow, C. J. Pudsey, J. A. Howe, J.-C. Faugères and A.R. Viana), Geological Society, London, Memoir, 22, 443-455.

Swart, N.C., Lutjeharms, J.R.E., Ridderinkhof, H. and de Ruijter, W.P.M. (2010) Observed characteristics of Mozambique Channel eddies. Journal of Geophysical Research: Oceans, 115. Available at: http://dx.doi.org/10.1029/2009JC005875.

Tew-Kai, E. and Marsac, F. (2009) Patterns of variability of sea surface chlorophyll in the Mozambique Channel: a quantitative approach. Journal of Marine Systems, 77, 77-88.

Ullgren, J.E., van Aken, H.M., Ridderinkhof, H. and de Ruijter, W.P.M. (2012) The hydrography of the Mozambique Channel from six years of continuous temperature, salinity, and velocity observations. Deep Sea Research Part I: Oceanographic Research Papers, 69, 36-50.

Verdicchio, G. and Trincardi, F. (2008) Shallow-water contourites. In: Contourites. Developments in Sedimentology 60 (Eds M. Rebesco, A. Camerlenghi), pp. 409-433. Elsevier, Amsterdam.

Viana, A.R. (2001) Seismic expression of shallow-to deep-water contourites along the south-eastern Brazilian margin. Marine Geophysical Researches, 22, 509-521.

Viana, A.R. and Faugères, J.C. (1998) Upper slope sand deposits: the example of Campos Basin, a latest Pleistocene-Holocene record of the interaction between alongslope and downslope currents. Geological Society, London, Special Publications, 129, 287-316.

Viana, A.R. and Rebesco, M. (2007) Economic and Palaeoceanographic Significance of Contourite Deposits. Geological Society, London, Special Publication, 276, 350 pp.

Viana, A.R., Faugères, J.-C. and Stow, D.A.W. (1998) Bottom-current-controlled sand deposits - a review of modern shallow- to deep-water environments. Sedimentary Geology, 115, 53-80.

Weijer, W., de Ruijter, W.P.M., Dijkstra, H.A., van Leeuwen and P.J. (1999) Impact of Interbasin Exchange on the Atlantic Overturning Circulation. Journal of Physical Oceanography, 29, 22662284.

This article is protected by copyright. All rights reserved. 
Wynn, R.B., Masson, D.G. and Bett, B.J. (2002) Hydrodynamic significance of variable ripple morphology across deep-water barchan dunes in the Faroe-Shetland Channel. Marine Geology, 192, 309-319.

Wyrtki, K. (1973) Physical oceanography in the Indian Ocean. In: Ecological Studies. Analysis and Synthesis (Ed. B. Zeitzschel), pp. 18-36, Springer-Verlag, Berlin.

You, Y. (1997) Seasonal variations of thermocline circulation and ventilation in the Indian Ocean. Journal of Geophysical Research, 102, 10391-10422.

Zhang, Y., Liu, Z., Zhao, Y., Wang, W., Li, J. and Xu, J. (2014) Mesoscale eddies transport deep-sea sediments. Scientific Reports, 4, 5937.

Zhang, L., Buijsman, M.C., Comino, E. and Swinney, H.L. (2017) Internal wave generation by tidal flow over periodically and randomly distributed seamounts. Journal of Geophysical Research: Oceans, $122,5063-5074$.

This article is protected by copyright. All rights reserved. 


\section{FIGURE CAPTIONS}

Fig. 1. Bathymetry of the Mozambique Channel (GEBCO and PAMELA cruises) showing the main circulation patterns (based on Schott et al., 2009) and the location of the seamounts and atoll analyzed in this study. SEC = South Equatorial Current; NEMC = North-east Madagascar Current; SEMC = South-east Madagascar Current.

Fig. 2. (A) Potential temperature-salinity diagram obtained from conductivity-temperature-depth (CTD) profiles on the seamounts and (B) potential temperature-oxygen diagram at the same stations. The grey lines represent the isopynals $\left[\sigma_{0}\right.$ : Potential density anomaly $\left.\mathrm{kg} \mathrm{m}^{-3}\right]$. The main water masses present above the fields of sand dunes are labelled: TSW = Tropical Surface Water; STSW = SubTropical Surface Water; SICW = South Indian Central Water.

Fig. 3. (A) Multibeam bathymetry of the Sakalaves Seamount with the sediment bodies outlined by black dashed lines. The dune crests are represented with black solid lines. The arrows represent the velocity near the sea floor (at 20 to $80 \mathrm{~m}$ above the sea floor) obtained with hull-mounted ADCP (38 $\mathrm{kHz}$ ) during the PAMELA-MOZ4 survey (light blue) and the PTOLEMEE survey (dark blue). The size of the arrow is proportional to the speed. Fault escarpments are represented with white dashed lines (based on Courgeon et al., 2016). (B) Backscatter image showing in black the areas covered by sediment. (C) Slope map of a zone with dunes to highlight the dune morphology. The blue arrow shows the migration of the dunes interpreted from the dune asymmetry.

Fig. 4. Photographs of the sea floor showing the different types of substrates: dunes and ripples, carbonate rocks and volcanic rocks at Sakalaves Seamount, Bassas da India Atoll, Jaguar Bank and Hall Bank. See Figs 3A, 7, 8A and 9A for locations.

This article is protected by copyright. All rights reserved. 
Fig. 5. Multi-channel high-resolution mini GI gun seismic reflection profiles PTO-HR-104 in Sakalaves Seamount, PTO-HR-039 in the deep terrace of Bassas da India Atoll and PTO-HR-058 in the Jaguar Bank. The blue lines show the direction of the dune migration interpreted from dune asymmetry. See Figs 3B, 6A and 7A for location.

Fig. 6. (A) Multibeam and lidar bathymetry of Bassas da India, with the sand extension outlined with black dashed lines. The blue arrows show the migration of the dunes interpreted from the dune asymmetry. Faults are represented with white dashed lines (based on Courgeon et al., 2016, 2017). T1: shallow terrace (200 to $240 \mathrm{~m}$ ). T2: deep terrace (440 to $540 \mathrm{~m}$ ). (B) Lidar bathymetry of the top of Bassas da India and backscatter image of the slope, showing in black the areas covered by sediment.

Fig. 7. Slope map of the Bassas da India terraces showing the presence of different dune fields. The blue arrows show the migration of the dunes interpreted from the dune asymmetry. The orange dot represents the location of the sediment sample MOZ1-KGS5 collected with a USNEL box corer.

Fig. 8. (A) Multibeam bathymetry of the Jaguar Bank with the sediment bodies outlined with black dashed lines. Fault escarpments are represented with white dashed lines (based on Courgeon et al., 2016) (B) Backscatter image showing in black the areas covered by sediment. Note that these areas are located in depressions related to faults. (C) Multibeam bathymetry of the dune field showing the migration of the dunes towards the NE (interpreted from dune asymmetry), almost parallel to the fault.

Fig. 9. (A) Multibeam bathymetry of the Hall Bank showing the location of mooring site MLP4. (B) Backscatter image showing in black a zone with sand in a circular depression on the top of the bank.

This article is protected by copyright. All rights reserved. 
Fig. 10. (A) Relationship between dune height $(h)$ and dune wavelength $(\lambda)$ at Sakalaves Seamount (blue colour), Jaguar Bank (green colour) and Bassas da India terraces (red colour) and comparison with the global trend (Flemming, 1988). The blue, green and red colour lines represent the regression lines for each group of dunes. The grey vertical lines show the grain-size as a function of the dune size (after Flemming, 2000). The orange dot shows the size of a dune sampled with a box corer in Bassas da India terrace (MOZ1-KGS5). The sample was collected at the trough of the dune. (B) Box and whisker plot displaying the minimum, maximum, median, lower quartile and upper quartile of the $h / \lambda$ ratio at Sakalaves Seamount (blue), Jaguar Bank (green) and Bassas da India Atoll (red).

Fig. 11. Relationship between water depth, slope angle and (A) dune height or (B) dune wavelength.

Fig. 12. (A) Grain-size distribution of the sediment sample (MOZ1-KGS5) collected in the deep terrace of Bassas da India. (B) Scanning electron microscope image from the dune sample, showing the presence of calcareous algae (CA), echinoderm fragments $(E c)$, benthic foraminifera $(B F)$, planktonic foraminifera (PF), bryozoans $(\mathrm{Br})$, pteropods $(\mathrm{Pt})$ and bivalves $(\mathrm{Bi}) . \mathrm{L}-\mathrm{BF}=$ large benthic foraminifera typical from shallow waters. See Fig. 7 for location.

Fig. 13. Speed, meridional component of the velocity $(v)$, zonal component of the velocity $(u)$, in situ temperature, oxygen, turbidity and bottom shear stress $(\tau)$ time series at mooring site MLP4 at $30 \mathrm{~m}$ above the sea floor. The black line represents the running average. The red bands show two periods of rapid changes in current direction, temperature and oxygen. The orange horizontal line in the bottom shear stress plot shows the critical bottom shear stress for erosion of the sediment sample collected on the deep terrace of Bassas da India Atoll.

This article is protected by copyright. All rights reserved. 
Fig. 14. (A) Progressive vector diagram, showing a general trend of the currents towards the northwest and some changes in direction related to the presence of eddies near the mooring site. (B) Spectra of kinetic energy based on the speed data from mooring MLP4 (blue line) and 98\% confidence level (red lines). M2 is the semi-diurnal tide (12.42 h) and M4 is the quatridiurnal tidal constituent (6.21 h). See Figs 1 and 9 for mooring location.

Fig. 15. Vector plot of the velocity with the speed represented in the $y$ axis. The arrow size also represents the current intensity and the orientation of the arrows represent the current direction (northward $=$ upward). Speed, bottom shear stress $(\tau)$, turbidity and in situ temperature obtained at $30 \mathrm{~m}$ above the sea floor at mooring site MLP4 during three days in May 2015; and depth, obtained from pressure sensors during the same time at two deeper mooring sites MLP3 and MLP5. No pressure data are available at site MLP4. The black lines represent the running average. Note that current velocity, in situ temperature and turbidity are modulated by tides. The orange bands show the periods of high turbidity that are correlated with weaker current velocity, lower temperature and from high to low tide. See Figs 1 and 9 for mooring location.

Fig. 16. Sea level anomaly (SLA) and geostrophic velocity anomalies (black arrows) in the Mozambique Channel showing the interaction of large anticyclonic eddies (positive anomalies in red colour) near the seamounts. Bathymetric contours are represented every $500 \mathrm{~m}$.

This article is protected by copyright. All rights reserved. 


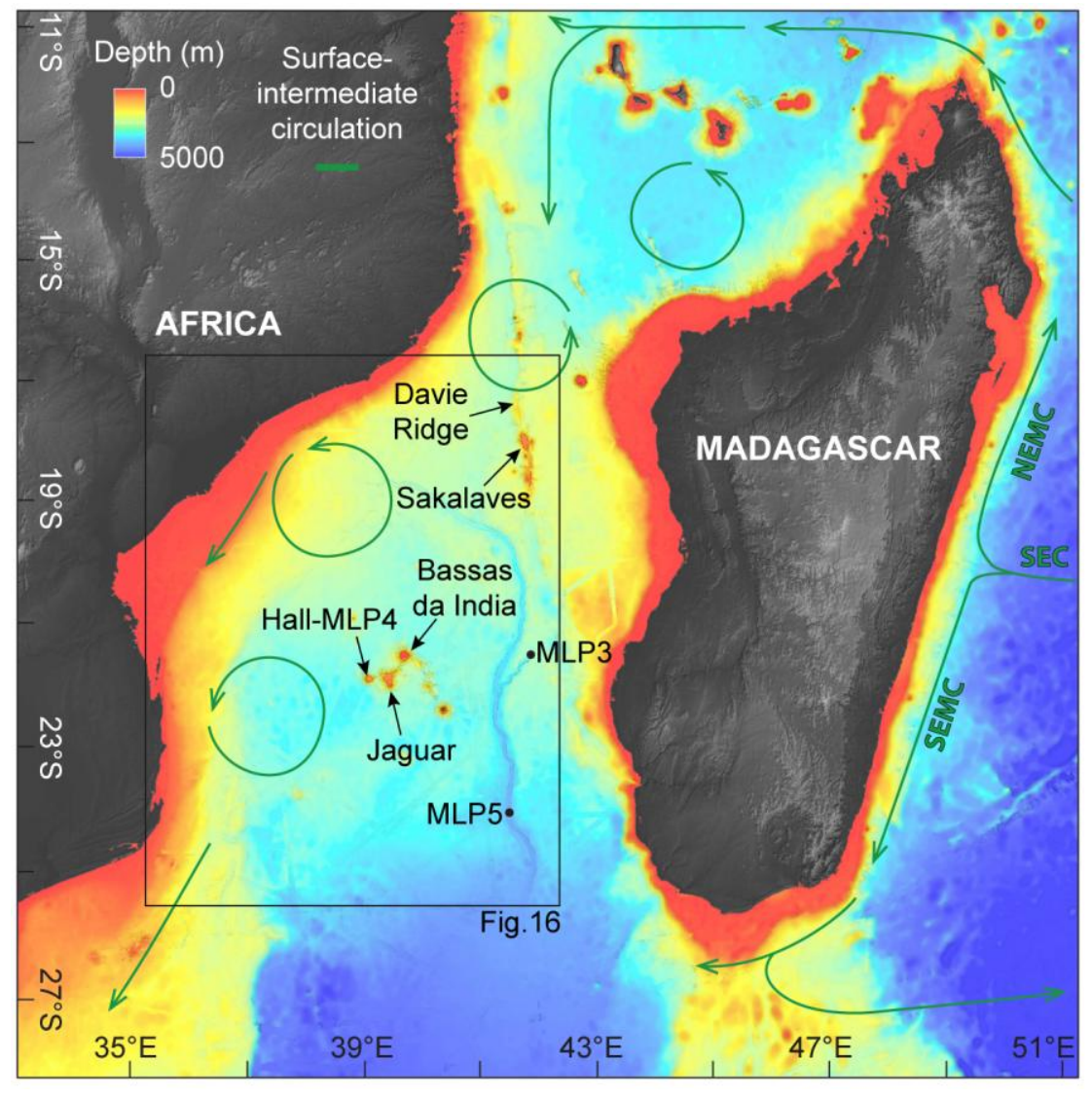

This article is protected by copyright. All rights reserved. 

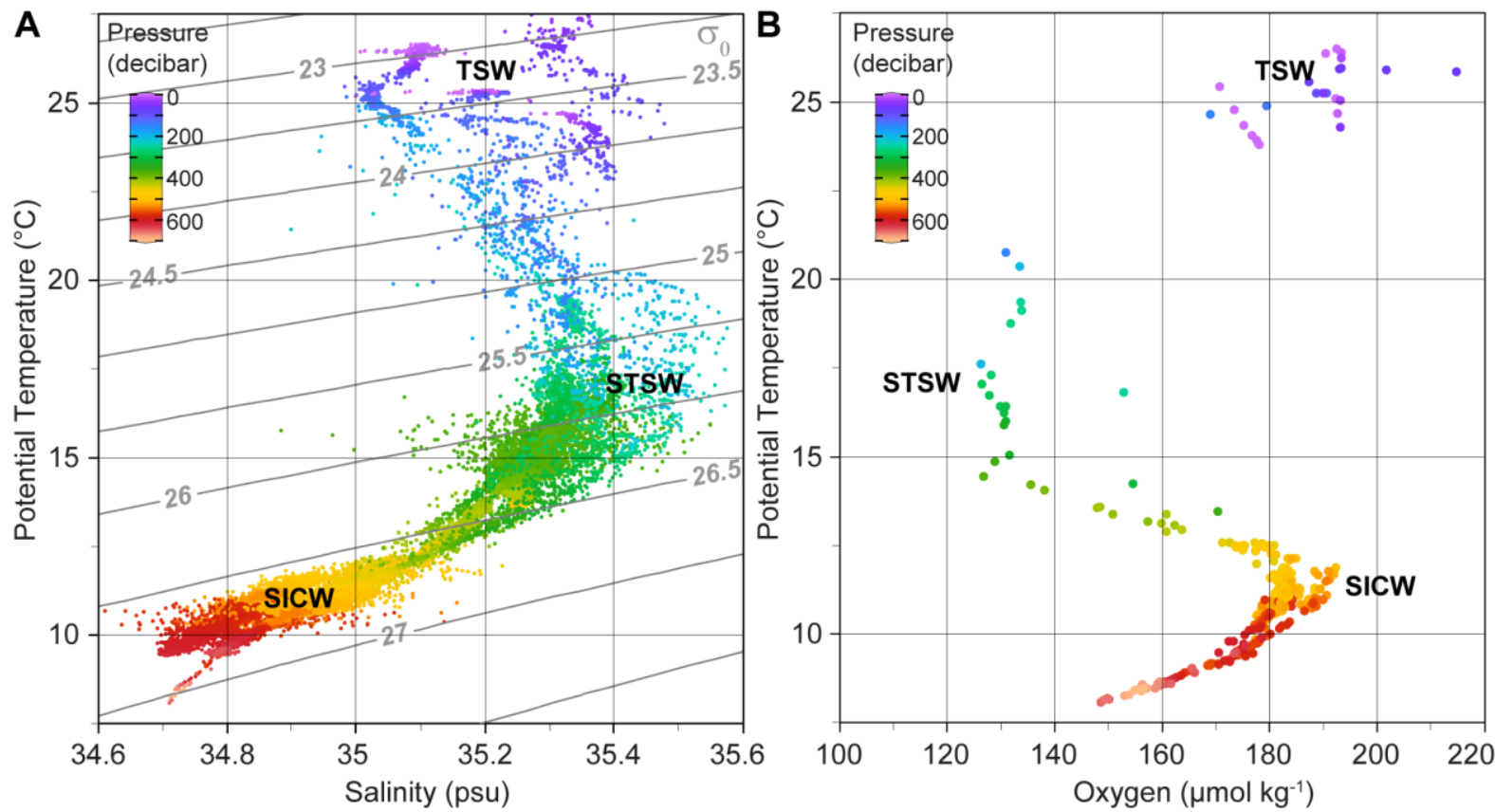

This article is protected by copyright. All rights reserved. 


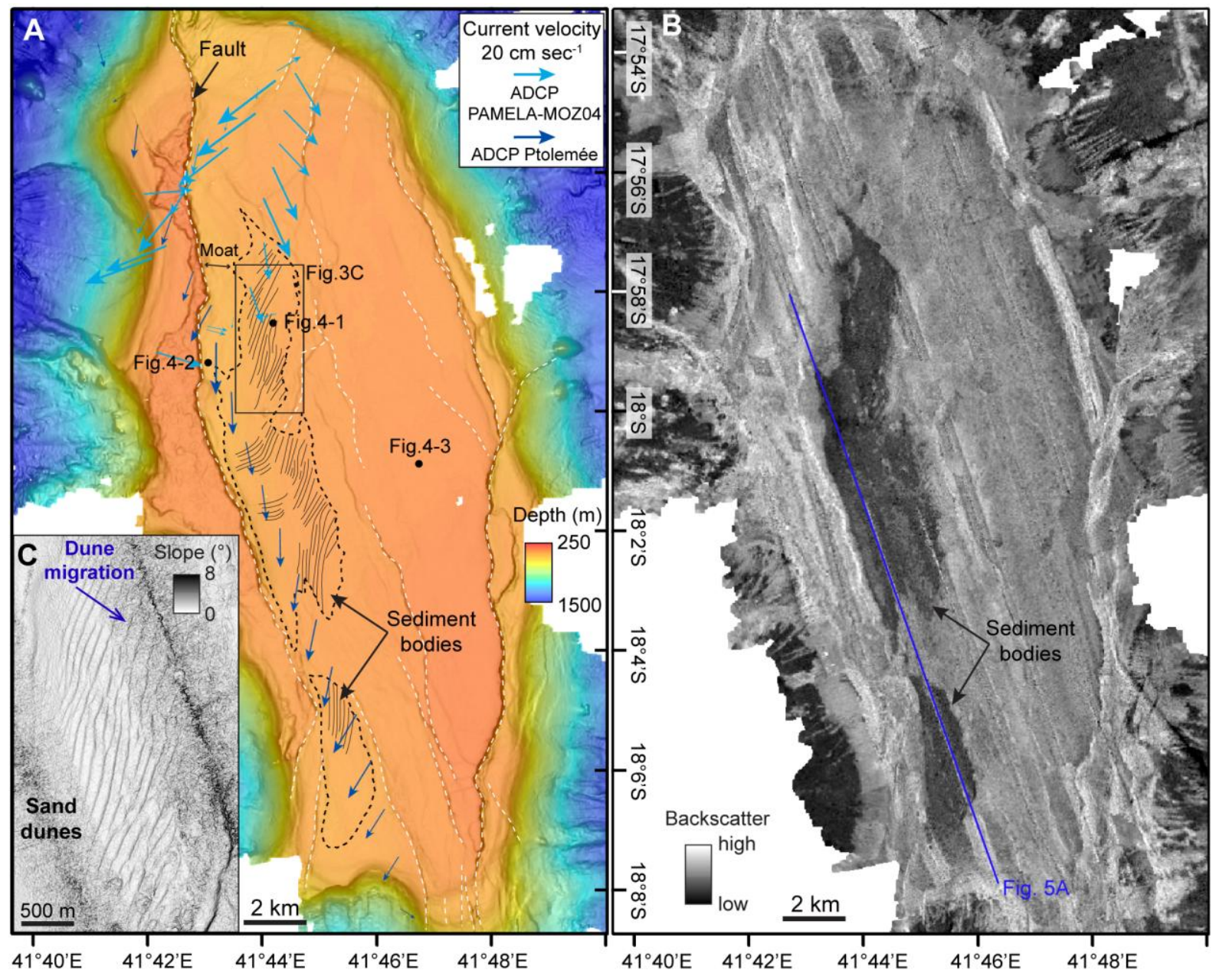

This article is protected by copyright. All rights reserved. 


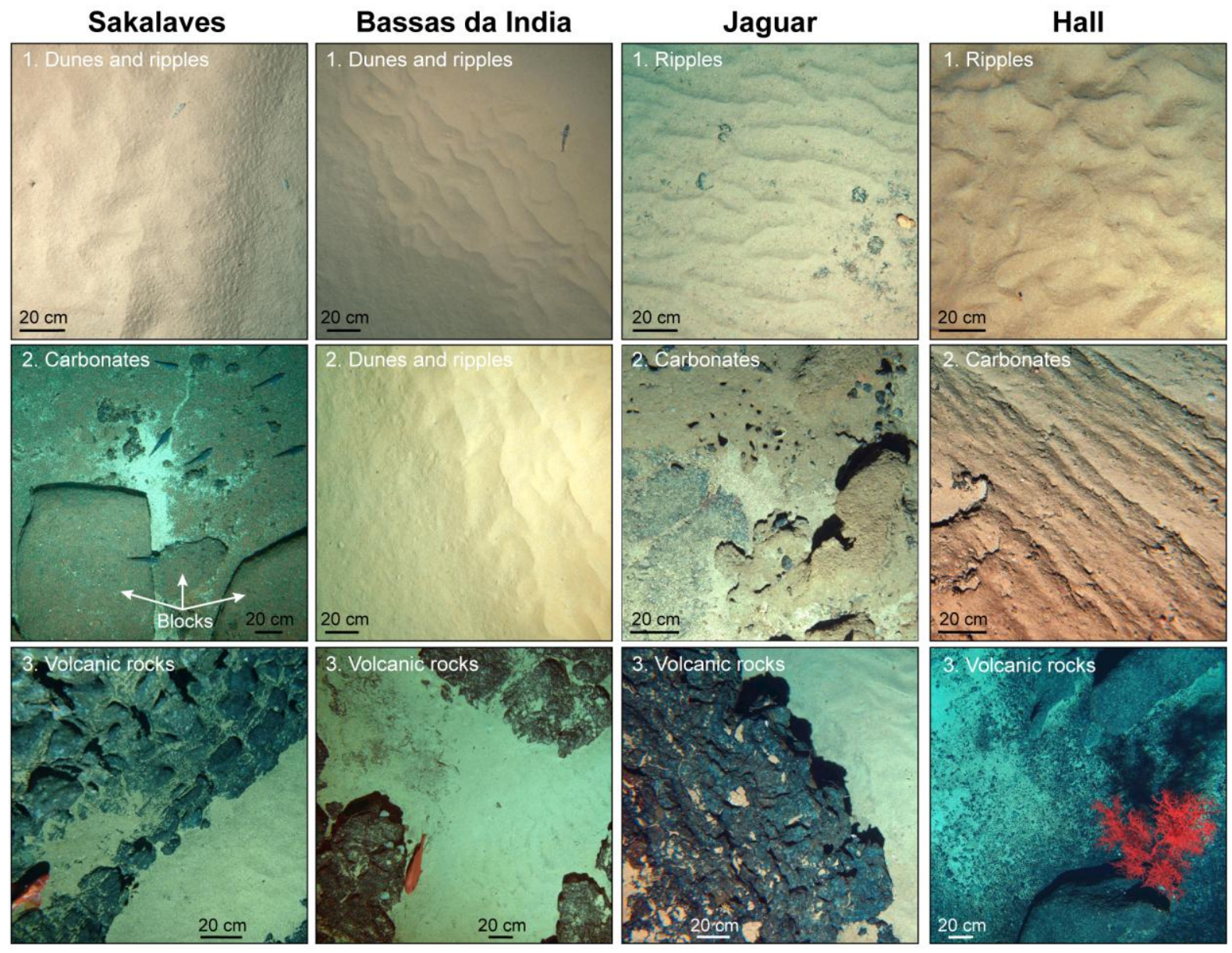

This article is protected by copyright. All rights reserved. 


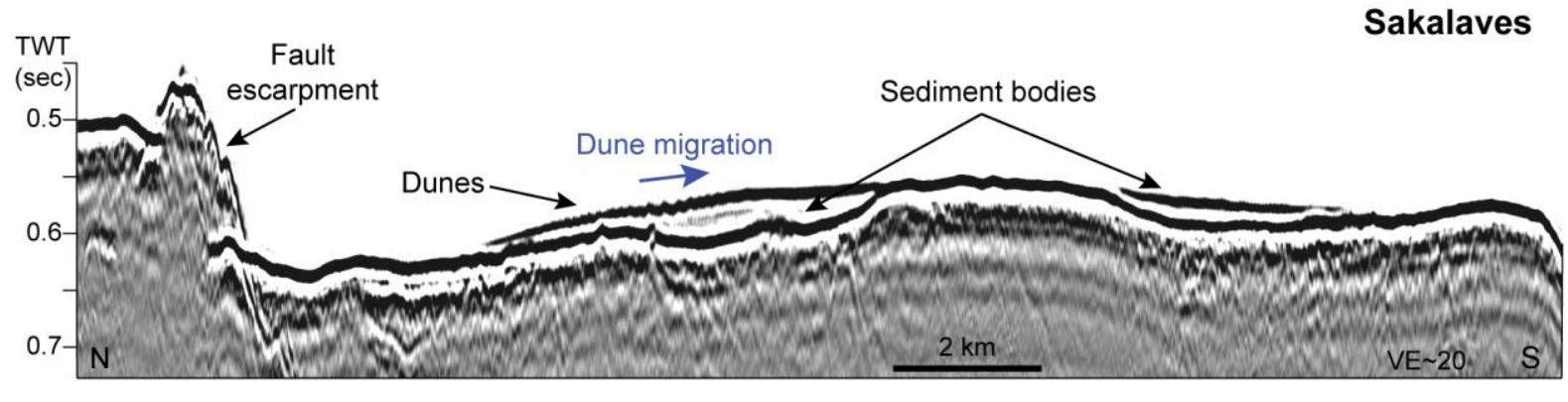

Bassas da India
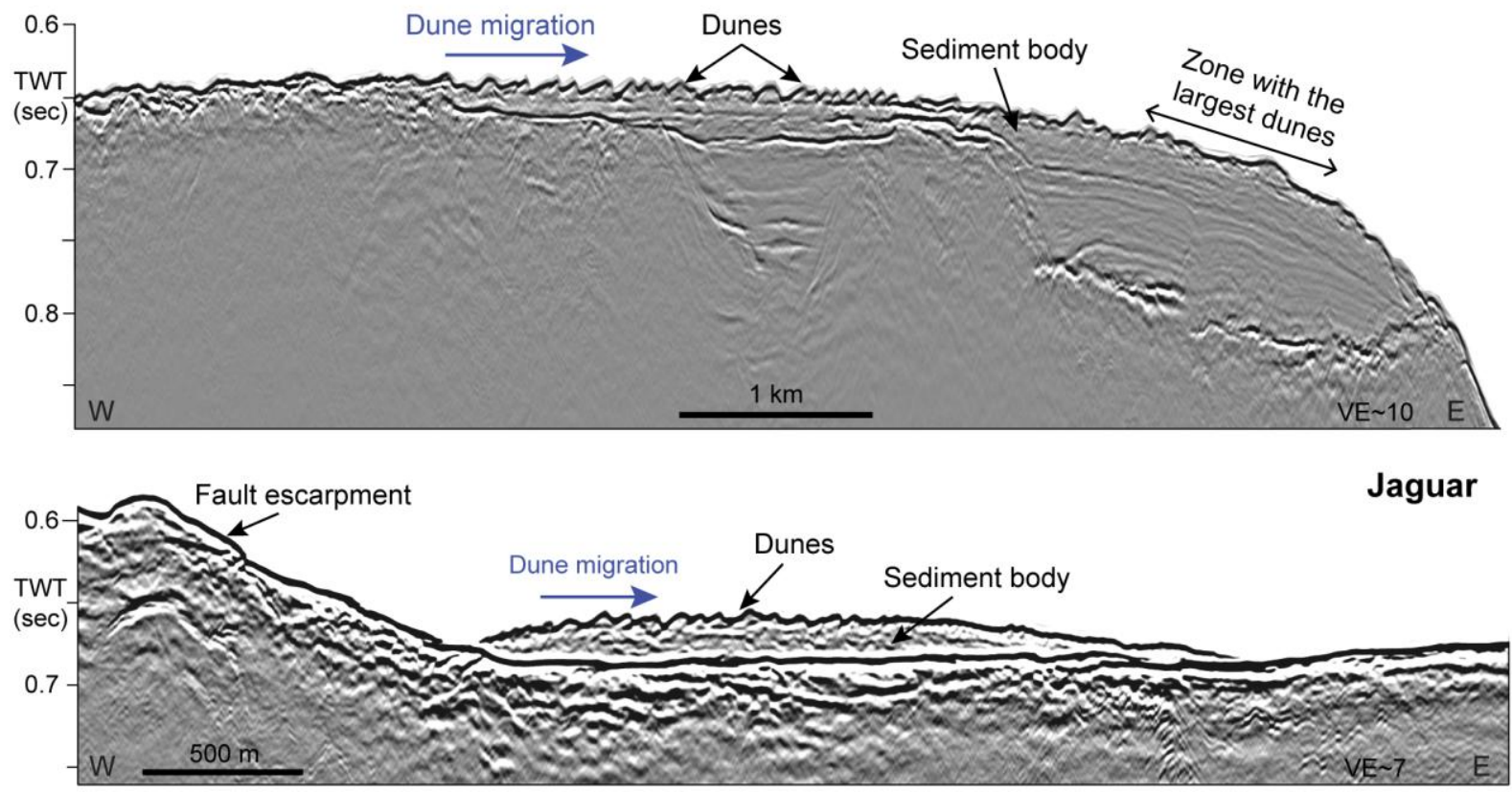

This article is protected by copyright. All rights reserved. 


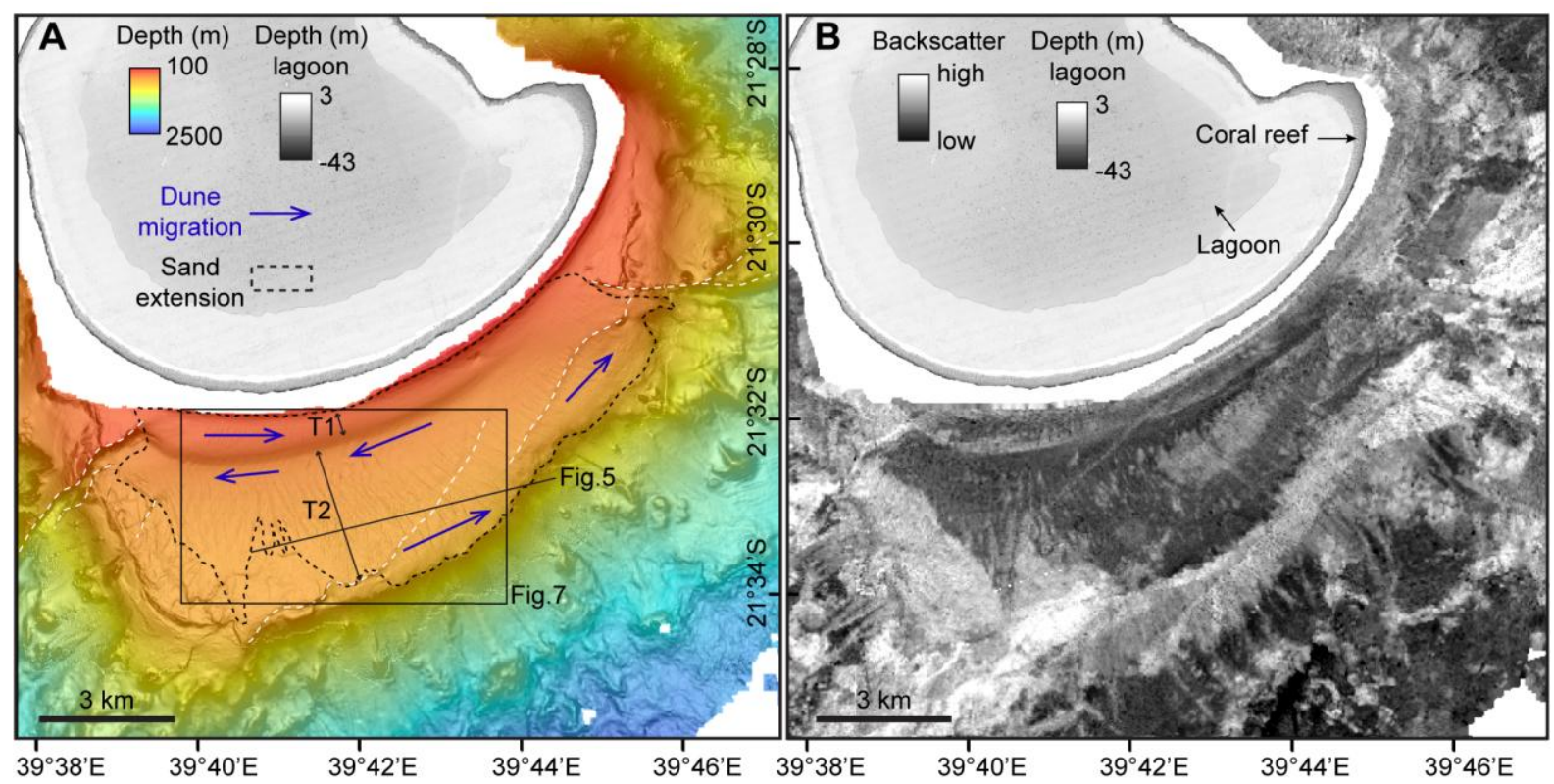

This article is protected by copyright. All rights reserved. 


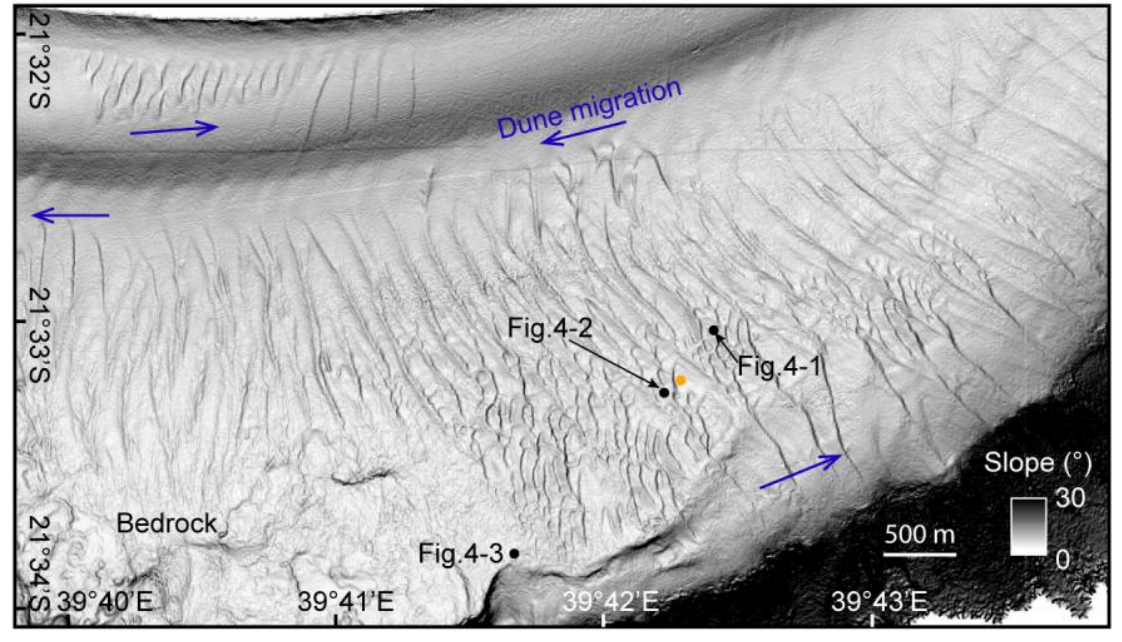

This article is protected by copyright. All rights reserved. 


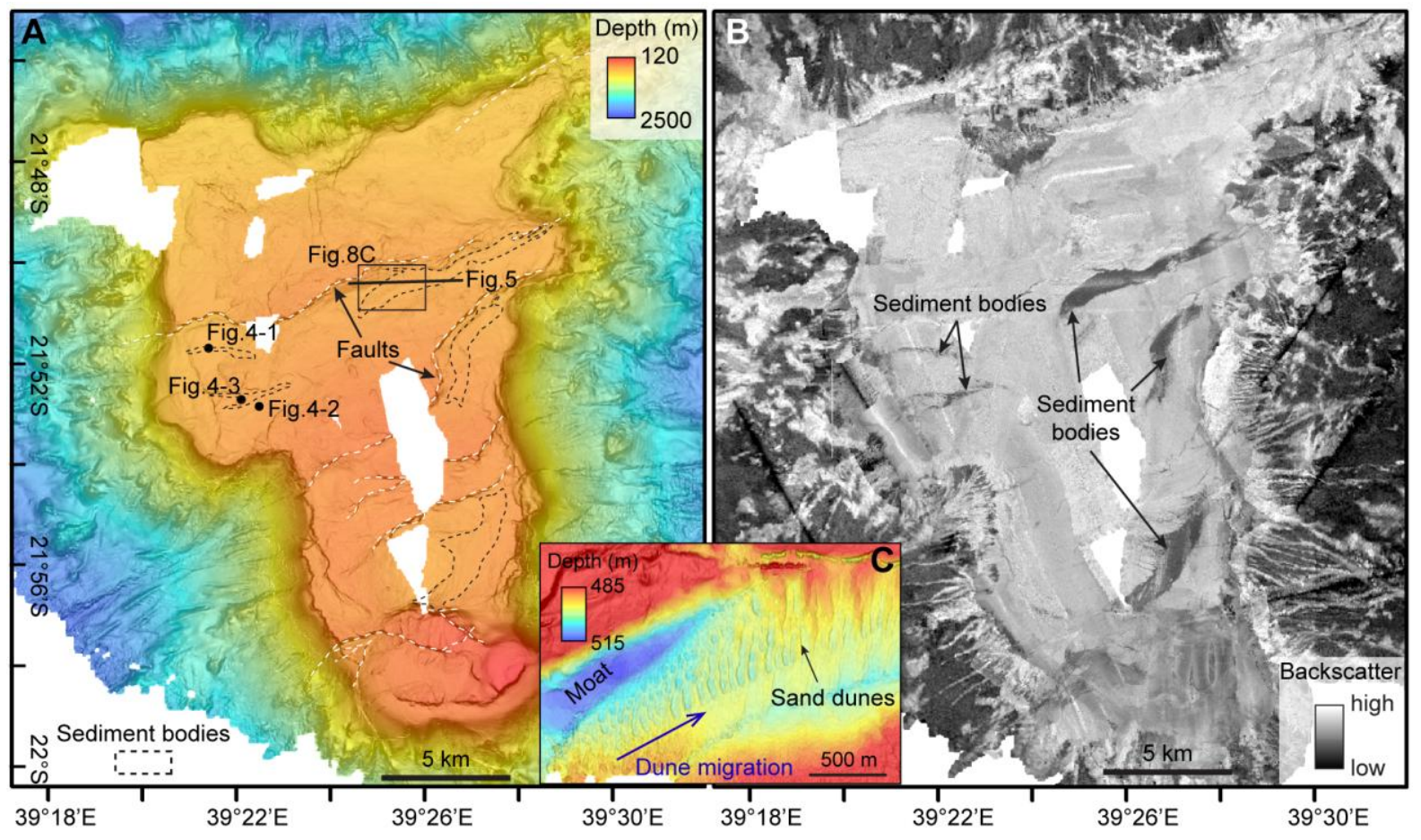

This article is protected by copyright. All rights reserved. 


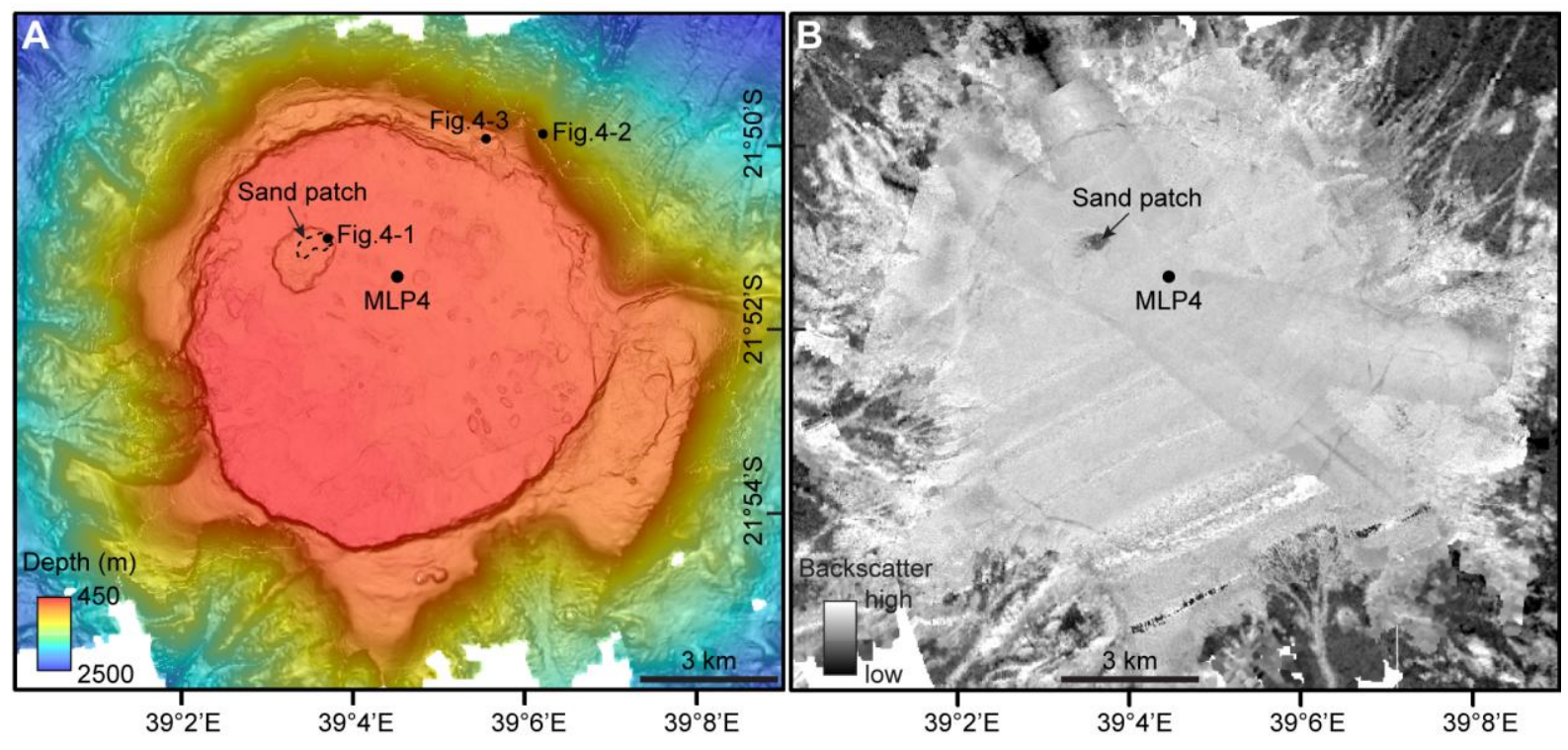

This article is protected by copyright. All rights reserved. 


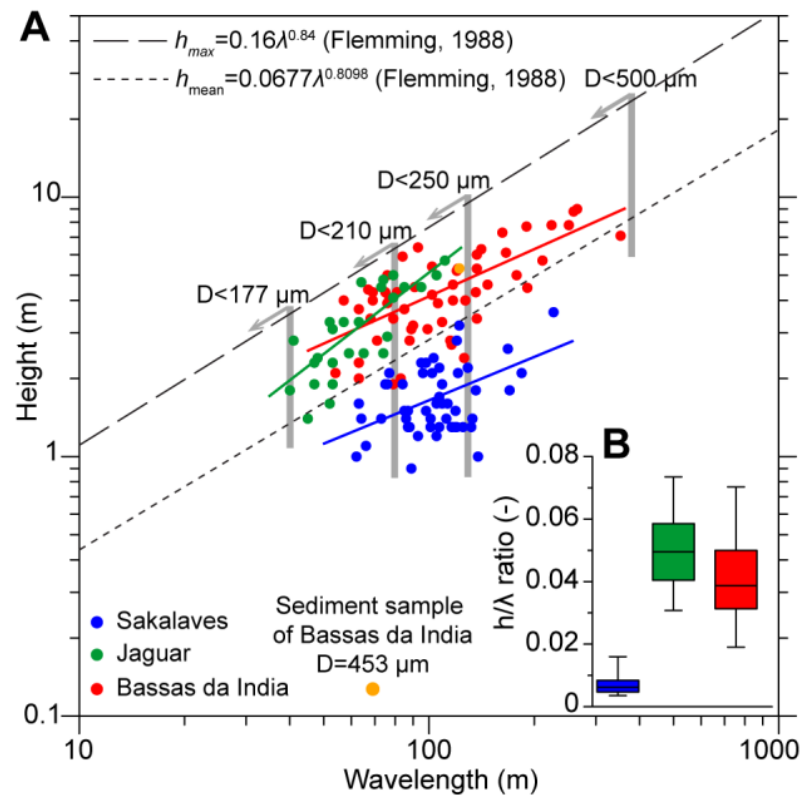

This article is protected by copyright. All rights reserved. 

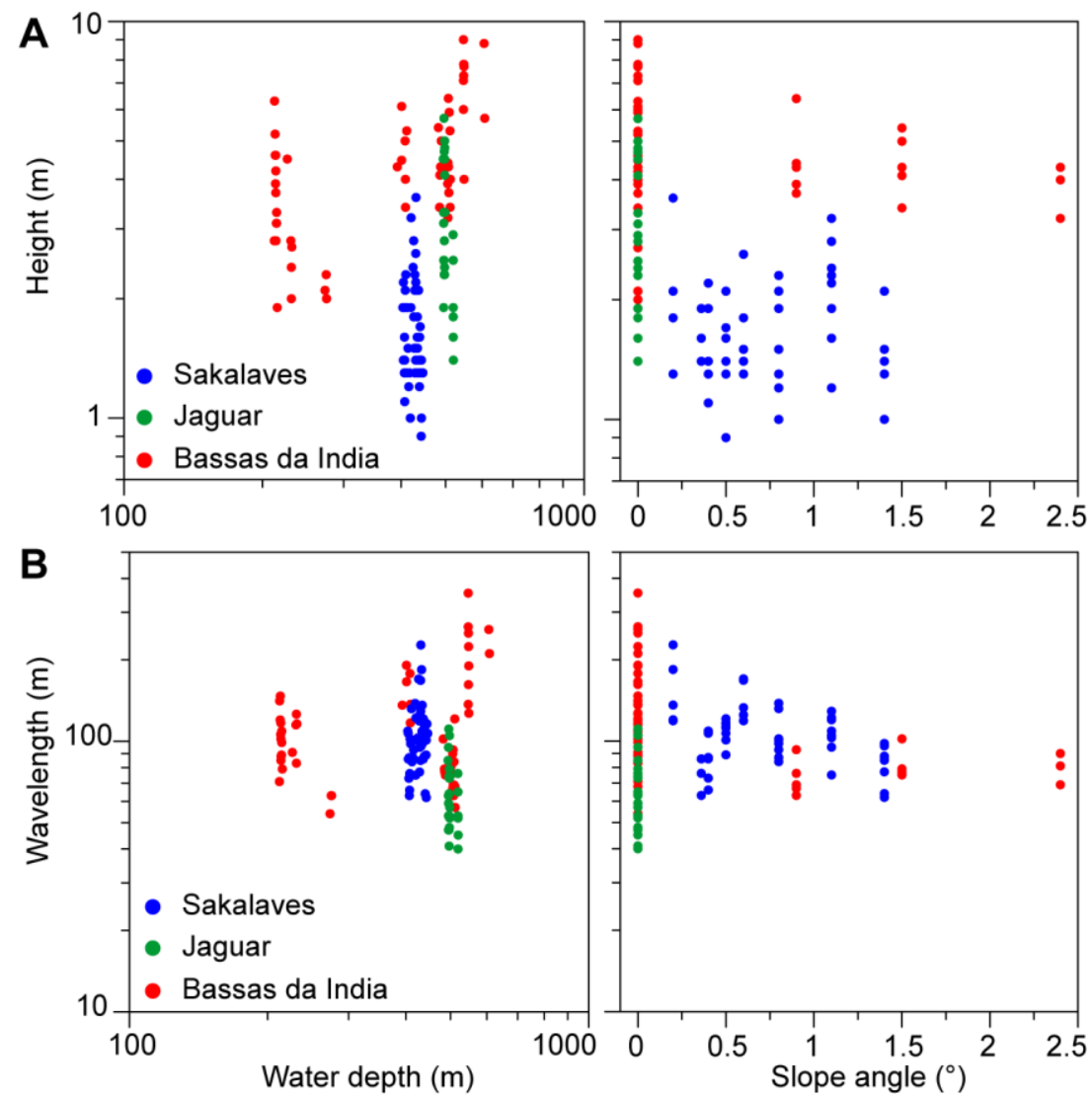

This article is protected by copyright. All rights reserved. 

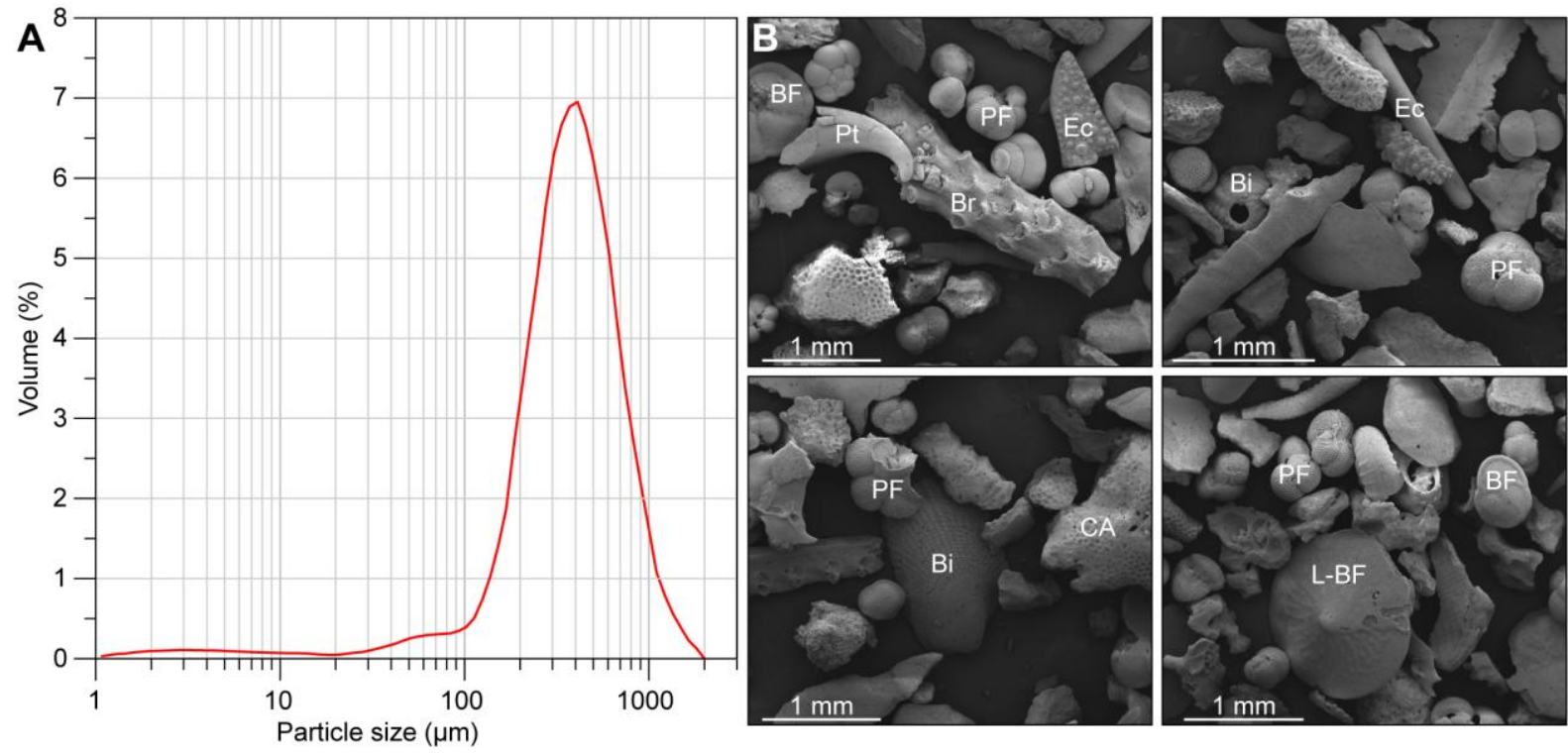

This article is protected by copyright. All rights reserved. 


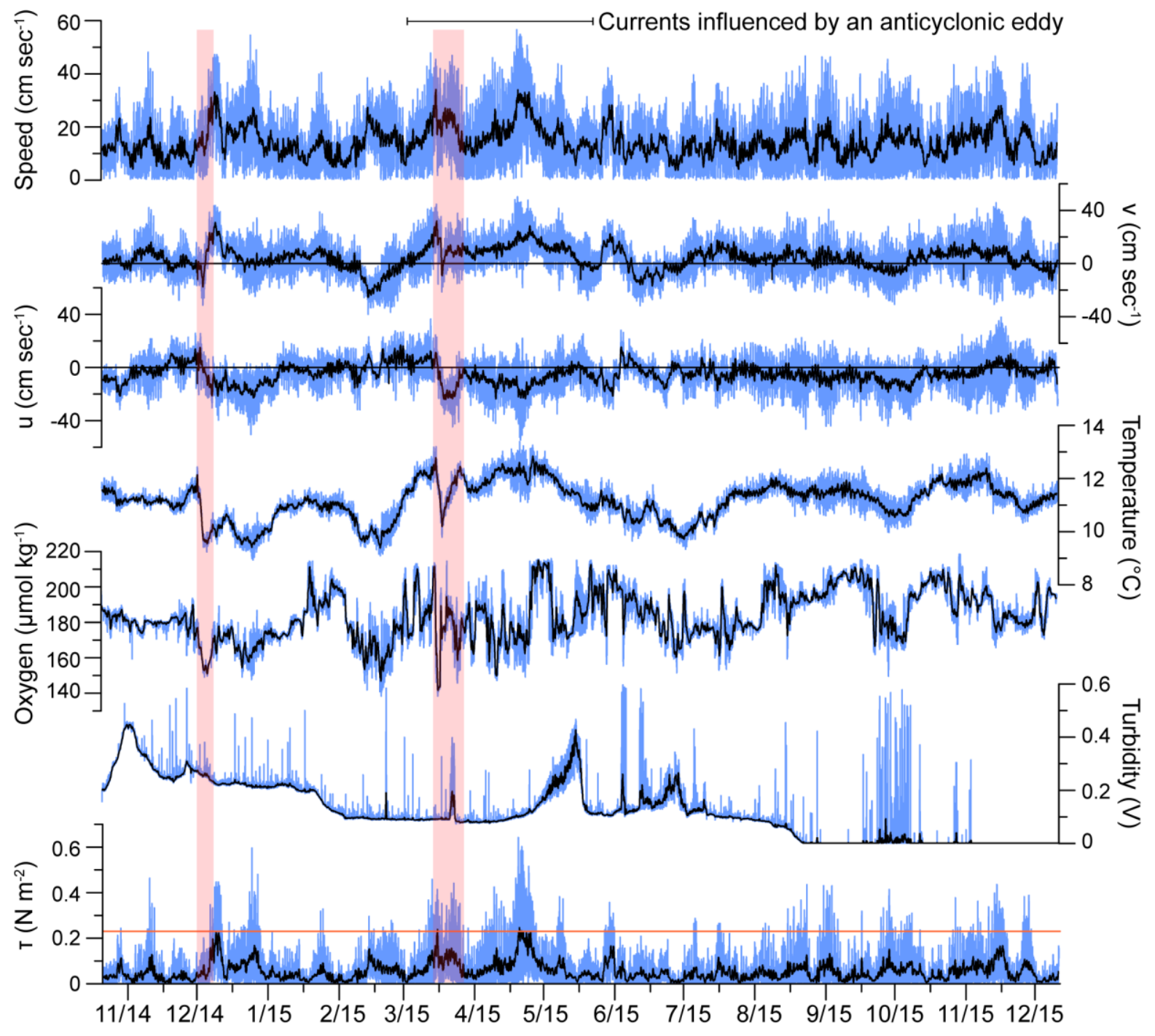

This article is protected by copyright. All rights reserved. 

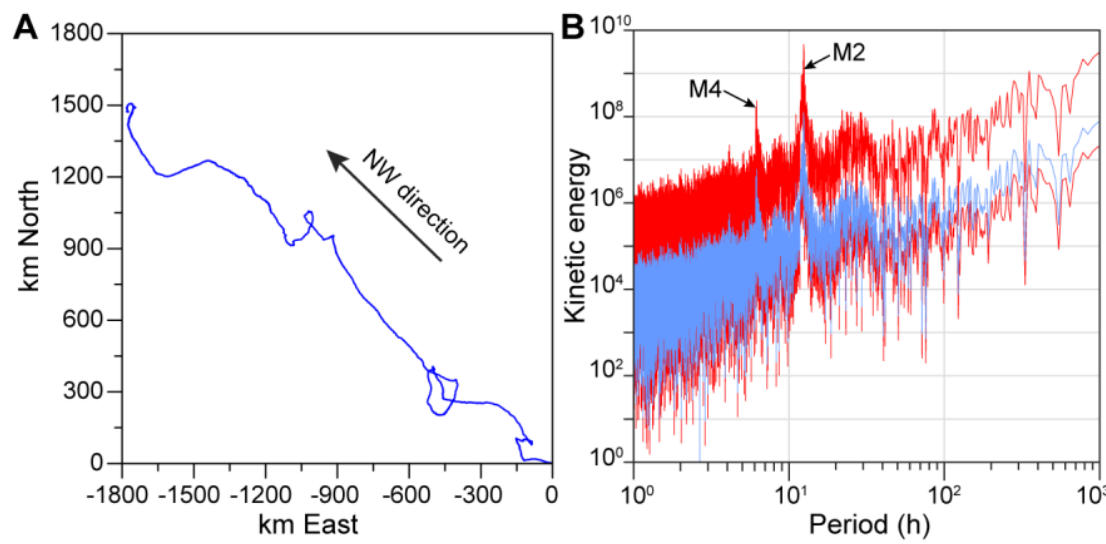

This article is protected by copyright. All rights reserved. 


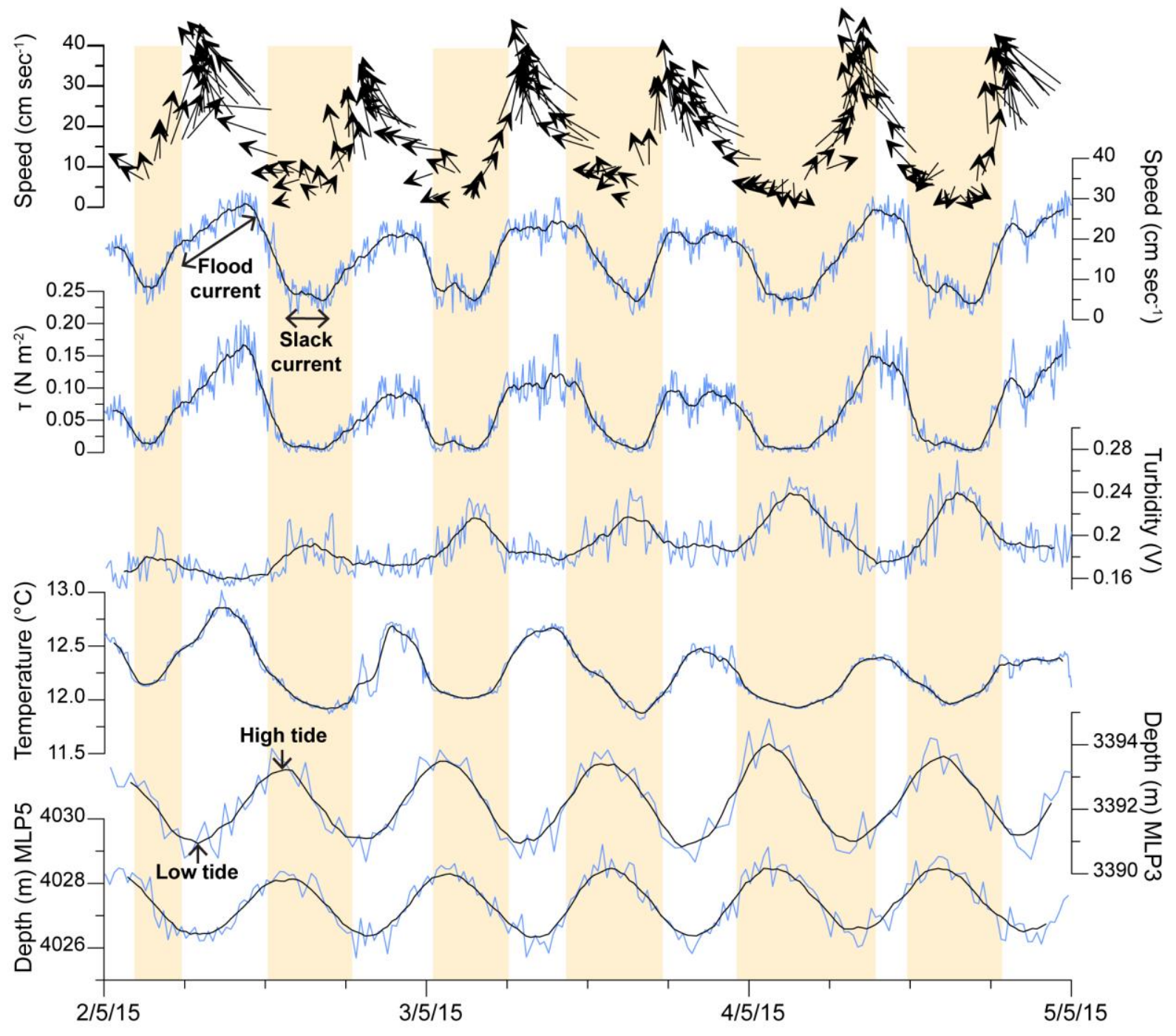

This article is protected by copyright. All rights reserved. 


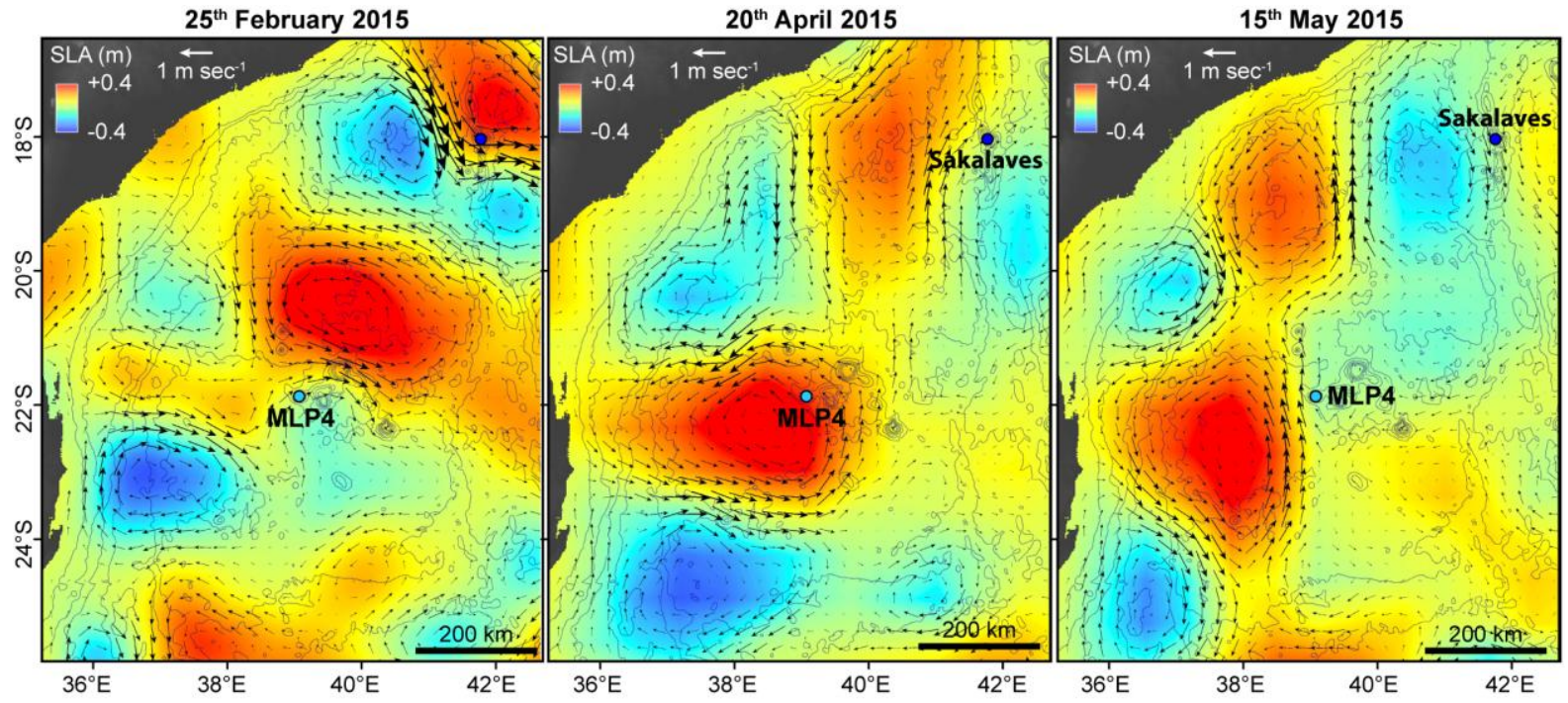

This article is protected by copyright. All rights reserved. 